\title{
A Comparative Study on Drivers for Corporate Environmental Responsibility, EU15 vs. EU-NMS13
}

\author{
Mariana Hatmanu, Christiana Brigitte Sandu *(D) and Elisabeta Jaba \\ Faculty of Economics and Business Administration, Alexandru Ioan Cuza University of Iasi, 22, Carol I Avenue, \\ 700505 Iasi, Romania; mariana.hatmanu@uaic.ro (M.H.); ejaba@uaic.ro (E.J.) \\ * Correspondence: christiana.balan@uaic.ro \\ Received: 7 September 2019; Accepted: 9 November 2019; Published: 14 November 2019 \\ check for \\ updates
}

\begin{abstract}
The activity of enterprises has a major impact on the quality of the environment Deterioration and abusive exploitation of resources, with no concern for environmental protection, bring the need for a higher level of corporate environmental responsibility (CER). Consequently, CER has become a sine qua non concern of small and medium enterprises (SMEs). This study aims to estimate the importance of drivers for CER. It was conducted on a sample of SMEs from two groups of EU countries characterised by a different level of social and economic development backgrounds. The authors applied statistical analysis to estimate the importance of the effect of drivers for CER using the logit model and the nomogram. The logit model shows that the most important effects of drivers for CER correspond to the company's core values, the impact of resource efficiency actions on the production costs, and the return on the investments made on resource efficiency. The magnitude of these effects is different for the SMEs from the two EU groups. Also, the study underlines the significant effect of SMEs' size for CER. The differences for the two groups of countries call for policies stimulating environmental responsibility, differentiated by the two types of SMEs.
\end{abstract}

Keywords: corporate environmental responsibility; SMEs; green products and services; logit model; nomogram

\section{Introduction}

In general, citizens and enterprises give special importance to higher environmental responsibility as to improve the quality of air, water, soil, and daily life.

Numerous studies report that the motivation of enterprises to act responsibly towards the environment stems from the interactions of enterprises' internal environment and their external environment, which includes governments, consumers, non-governmental organisations, and competitors [1-3]. Moreover, fair trade, environmentally friendly products, or organic farms show that products made in a sustainable manner are economically profitable and bring social benefits [4]. Therefore, the issue of corporate sustainability assessment has been vital in assuring the market success of corporations through innovation and strategy [5].

Up to the 1980s, the responsibility of companies towards the environment and society had been mostly informal; some of them voluntarily included into their annual reports sections referring to social and environmental performance [6]. In the 1980s, the concept of "corporate responsibility" started to be formally approached after the establishment of the World Commission on the Environment of the United Nations and the adoption of the Brundtland Report in 1987. The 1987 report established three main elements of sustainable development-environmental protection, economic growth, and social equity-putting a special emphasis over the consumption of Earth's resources $[7,8]$. 
The concept of corporate responsibility appears in the literature as corporate social responsibility (CSR), corporate social and environmental responsibility (CSER), and corporate environmental responsibility (CER).

Corporate social responsibility (CSR) is a growing business practice that integrates sustainable development into the business model of an enterprise and has a positive impact on its social, economic, and environmental standing. CSR also stresses that a corporation has both economic and legal duties, as well as ethical and philanthropic responsibilities [9].

In 2011, the European Commission revised the definition of corporate social responsibility (CSR), considering that, "to fully fulfil their social responsibilities, enterprises should have at their disposal a procedure that would integrate their social, ethical, environmental, human rights and consumer protection concerns [ ... ], aimed to (i) stimulate the creation of common values [ ... ] (for the owner/shareholders, and other stakeholders and for the society, in general; (ii) identify, prevent and reduce the potential negative effects that enterprises might have." According to this definition, social responsibility comprises environmental responsibility, although the word "environment" has not been included into the acronym CSR [10].

Corporate social and environmental responsibility (CSER) refers to the commitment of companies to reach both social and environmental goals. The term CSER refers to the following actions: Compliance with regulations, voluntary initiatives, responsibility, communication, and transparency, as well as institutionalisation of environmental and social issues [11]. The different attitudes of companies towards the environment are justified as they have to comply with environmental regulations and actions, and be profitable and competitive. Corporate social and environmental responsibility lies between social awareness and profit-making for shareholders. Corporations are becoming increasingly aware that being socially and environmentally responsible has been turned into a business advantage [11].

Corporate environmental responsibility (CER) comprises corporate practices related to management and the use of natural resources, waste production and disposal, sale and recycling of environmental goods, and prevention and control of pollution [12]. In other words, corporate environmental responsibility refers to the way in which corporations undertake their responsibility to minimise and manage the negative impact of their operations on the environment [13].

CER deals with a company's relationship with the environment. It contains the obligations of decisionmakers to take responsible actions, which aim to protect and improve the environment as a whole, and which are also in line with their own interests [14].

According to Gunningham [15], CER is defined as the practices that benefit the environment or mitigate the adverse impact of business on the environment that go beyond those that companies are legally obliged to carry out.

Both CSR and CER play a very important role in the development of efficient and effective company strategy. CSR focuses on social and environmental aspects while CER is linked to economic and environmental aspects.

In this study, we focused on assessing CER, namely, the environmental bevaviour of SMEs that carry out environmental practices that go beyond the minimum legally binding requirements.

To have sustainable growth, companies should produce sustainable green products and services with a lower environmental negative impact. The provision of green products and services to the market brings benefits to consumers, businesses, and the environment. SMEs have high flexibility in changing their activities and adapting to different contexts. Therefore, they can easily gain access to new niches on the sustainable goods and services market, with clear benefits for the environment.

A review of previous studies on CER undertaken by Orlitzky et al. (2011) [16] shows that the geographic focus is skewed as most countries represented in CER research are developed countries. North America covers $70 \%$ of the focus in CER articles while Europe adds up to $21 \%$, whereas just $6 \%$ of studies deal with China [16]. It could be explained by the fact that researchers are seeking well-set enterprises in established industries and they may exclude enterprises from emerging markets. Another review of articles focusing on international aspects of CER was accomplished by Holtbrügge and 
Dögl [17]. It was shown that single-country studies are prevalent while multicountry studies are largely under-represented. Based on their findings, they recommended that future studies should further investigate cross-country effects and focus on the transferability of CER practices across borders [17].

In this context, this study is a comparative analysis of a sample of SMEs from two groups of countries, namely, the EU15 countries (BE, DK, DE, IE; EL, ES, FR, IT, LU, NL, AT, PT, FI, SE, UK) and the EU-NMS13 countries (the 13 New Member States: BG, CZ, EE, HR, CY, LV, LT, HU, MT, PL, RO, SI, SK). To the best of our knowledge, this study is the first study investigating the difference in CER behaviour of green SMEs between the two groups of EU countries.

The difference in perceptions and strategic choices regarding corporate social responsibility between Central and Eastern European (CEE) and Western countries is based on a diversity of factors, such as state policies, macroeconomic circumstances, industrial norms, institutions, civil organizations, and community groups $[4,18,19]$. Moreover, the CEE countries tackle important environmental issues. A comparison of drivers for CER of SMEs in the two groups of countries may allow the EU-NMS13 countries to identify useful solutions that have already been implemented in highly industrialised EU15 countries.

The Central and Eastern European (CEE) countries have had a particular developmental path as they only passed to a capitalist economy after the 1990s and went through a transition to the market economy afterwards [20]. The technologies used for industrialisation in the two groups of countries led to differences in environmental responsibility. Industrialization based on technologies was done differently in the two groups of countries: Former communist countries used outdated and polluting technologies that had been abandoned in developed countries.

The aim of this study was to assess comparatively the importance of drivers for CER in SMEs of EU15 and EU-NMS13 countries. For this purpose, we set the following objectives: (i) To estimate the degree to which enterprises comply with environmental legislation; (ii) to explain the environmental responsibility of enterprises by factors; and (iii) to measure the impact of factors, characteristics, and motivations for corporate environmental responsibility (CER) by groups of EU countries.

In our research, we identified factors, characteristics, and motivations of CER and estimated the importance of their effects by groups of countries in order to provide data needed for designing best policies and decision-making in this area. The results of the study show that there are differences in corporate environmental responsibility among SMEs by groups of countries, EU15 and EU-NMS13. The estimated differences are explained by factors and motivations influencing the development of corporate environmental responsibility.

The paper is divided into five sections. After the introduction, the second section reviews the literature on drivers for CER and presents the research hypotheses. The third section describes the analysed data and the methodology. The main findings are outlined in the fourth section. The final section presents the discussion and conclusions.

\section{Literature Review and Hypotheses}

Environmental improvement is one of the three pillars, together with economic growth and social development, of good corporate governance. Good governance fosters sustainability and helps companies achieve their values. Therefore, companies realize long-term benefits, including reducing risks, attracting new investors and shareholders, and increasing the company's equity. However, the benefits of good governance are smaller in competitive industries than in non-competitive industries [21]. Consequently, the need to provide managers with incentives through good governance is higher for firms in non-competitive industries. The balance between good governance and corporate environment responsibility supports the company's efforts to build up a control mechanism, which will also enhance shareholder value and boost satisfaction with shareholders and stakeholders.

Motivated by the importance of the role of governance in shaping the socially responsible firm's behavior, recent papers have studied the relationship between the existence of compensation contracts linked to corporate social responsibility and corporate social responsibility activities [22]. The results 
obtained by Hong et al. [22] advocate for the effectivness of providing incentives for corporate social responsibility to managers on the firm's social performance. Therefore, it was found that this practice of connecting executives' compensation to corporate social responsibility objectives improves the corporate social standing. Moreover, other empirical studies have highlighted that corporate social responsibility and contingent compensation differs significantly by industries and by CSR categories and it is offered primarly by well-governed firms [23]. This compensation practice is considered an operational tool to increase firms' social performance. Furthermore, corporate social responsibility contracting influences managers' preference and activities, irrespective of their characteristics [24].

In research analyzing the drivers for CER, one might look at a set of factors and characteristics of SMEs and their motivations. In the context of the present study, the most important factors were considered and are discussed hereunder.

Customers can motivate companies to adopt responsible environmental behaviour and create green goods and services.

A demand from an external environment for green goods and services is one of the factors that has significant influence on corporate environmental behaviour [25]. Some studies found that a positive influence of consumers on green goods and services may bring long-term benefits to companies: Increased brand value, differentiation from competitors, consumer loyalty, and presence on new markets [26]. The study of Jahanshahi and Brem [27] in Iran, during 2016 to 2017, on a sample of 149 SMEs found that long-term relations built between companies and consumers of their goods may influence the environmental behaviour of these companies. Consumers, who are worried about the quality of goods and services and about environmental protection, may motivate companies to adopt a responsible environmental behaviour and, therefore, create goods and services that match the expectations of consumers towards environmental protection [28,29].

Enterprise image may influence its responsible environmental behavior.

A study conducted by Sáez-Martínez et al. [3] on SMEs from 38 countries reported that enterprise image, along with subsidies, business opportunities, and enterprise values and missions, is one of the motivations determining whether companies adopt a responsible environmental behaviour. One of the motivations stimulating a high degree of corporate responsibility refers to the awareness of an enterprise on the importance of its image and reputation [1]. Companies may be affected by the way in which their environmental performance is perceived by external entities. The community of investors, one of the entities of the external environment, has lately become more interested in environmentally friendly goods and services [11,30-32]. So, companies realize the importance of environmental protection when they create products and services, and beyond compliance with legislation, these companies voluntarily take measures ensuring corporate sustainability, and implicitly, better image and reputation [33,34].

Holtbrügge and Dögl [17] identified that intangible benefits, such as reputation, gain increasing importance when dealing with environmental practices. Outside of financial performance, enterprises are interested in maintaining a certain image that is consistent with the current external regulatory pressures.

Public support may determine a responsible environmental behavior.

Public support is another motivation for companies to be more environmentally responsible. The government, through its intervention, may provide public support to companies by reducing taxes and providing subsidies [3]. A study conducted by Henriques and Sadorsky in 1996 [22], comprising 400 companies, showed that the motivation of companies to implement responsible environmental strategies is positively influenced by the pressure exerted by governmental regulations and customers. Also, the support of loyal customers and recognition granted by other organizations may determine responsible environmental behaviour [35,36]. By reviewing several studies on CER, Holtbrügge and 
Dögl [17] found that external regulatory pressures, such as policy regulations, appear to be the most effective method in forcing companies to implement CER practices that are best for the environment and not just the firm's financial performance. Moreover, external regulatory pressures may be the solution for a greener world, which is an important implication for political decision makers [17]. As demonstrated in the multi-country studies on CER, this is valid for developed as well as developing countries to enhance competitiveness and to attract foreign direct investments (FDI) of environmentally responsible enterprises [17].

Enterprise core values may determine the inclination of companies towards adopting responsible environmental behavior.

Along with mission and vision, enterprise values lie at the foundation of organizational culture. Some core values include community, innovation, diversity, integrity, empowerment, and ownership. The company's culture identifies who its relevant customers, suppliers, competitors, and employees are, but it also shapes the way in which it interacts with these key actors. A study of Bansal and Roth [37], comprising 53 companies, found that the inclusion of environmental responsibility into enterprise values has determined such long-term benefits as avoidance of financial sanctions, reduction of risks, and employee satisfaction. Annandale and Taplin [38], in a study that included 26 Australian companies, ranked motivations determining whether companies adopted a responsible environmental behavior. Organisational culture holds first position in the ranking, followed i by the influence of consumers and other organisations. Bichta [39] studied Greek companies and concluded that organizational culture, as a whole, may create rules, by which enterprise members may demonstrate a specific behaviour. Nevertheless, in general, the values of members are those that may determine the inclination of companies towards responsible environmental behaviour.

Business opportunity may influence environmental corporate responsibility.

Business opportunities represent one of the motivations of an enterprise when it chooses to get involved in an environmentally responsible manner. A study of Nikolau and Evangelinos [40] found that, in companies with a high degree of environmental responsibility, there appears to be quantifiable business opportunities, through the appearance of new markets, on which these companies can distribute their products, and, where, implicitly, new consumers could be found. With new markets, companies acquire a competitive advantage compared to other environmentally responsible companies, or compared to companies not implementing responsible environmental practices. More recent studies have also reported the positive influence of business opportunities in environmentally responsible companies $[3,41]$.

CER may give competitive advantages to companies providing green products and services.

Competition is another motivation for companies to adopt a strategy that would also include environmental responsibility. Doran and Ryan [42], in a study conducted on a sample of Irish companies, observed that to prosper companies should go beyond the advantages of competition by providing more benefits to external entities (consumers, investors, etc.). Concerning environmental responsibility, some companies may provide competitive advantages, consolidating their image by differentiating goods and services they provide compared to other companies with a low degree of environmental responsibility [24,41].

Compliance with environmental regulations may determine companies being environmentally responsible.

According to academics and business leaders, the dominant driver for CER is government legislative policies [13]. Environmental challenges are increasing the pressure on governments to find ways to reduce environmental damage while minimizing harm to economic growth. Governments 
have a range of tools at their disposal, including regulations, information programs, innovation policies, environmental subsidies, and environmental taxes.

Environmental protection regulations motivate companies to make decisions on the degree of their environmental responsibility. Li et al. [43] contend that strict environmental protection regulations may determine that companies start practices for the creation of green goods and services. The study of Li et al. [43], comprising a sample of Chinese companies, found that the Chinese government, due to excessive pollution, forced a significant number of companies to become more environmentally responsible. Another study reported that, in the context of severe governmental environmental protection measures, companies have become more environmentally responsible, having avoided sanctions for non-compliance with these measures [44].

Tax incentives may influence the attitude of SMEs towards the environment.

The literature review highlights different results for the importance of tax incentives on corporate responsibility [45]. A tax incentive would indirectly encourage and motivate taxpayers. The existence of tax incentives can also be easier for taxpayers to comply with in performing their tax obligations.

Business leaders clearly stated their desire to see national governments taking a more active and leading role to encourage and even force greater environmental responsibility. Moreover, government incentives are a key driver for CER, especially in the opinion of academics [13].

In an empirical study on drivers for CER in SMEs, model of the dependent variable CER in relation to motivations for engaging in environmental practices was identified [3]. The main findings highlighted the partial validation of the hypothesis that environmental regulation (regulatory push/pull, subsidies, fiscal incentives) promotes the development of CER in SMEs [3].

Therefore, we appreciate that tax incentives, together with other government instruments, may play an important role in the development of CER.

Structural characteristics of companies may influence the attitude of SMEs towards the environment.

The structural characteristics of companies influence environmental behaviour.

Studies on CER of SMEs reported that the size, age, and sector of an enterprise may explain its attitude towards CER $[3,41]$. The European Commission underlines that SMEs, and especially micro-enterprises, may face the risk that their social and environmental responsibility could remain informal and intuitive [10].

In this study on CER, we considered such features (size, age, and sector) and motivations of SMEs as customers' demand, enterprise image, public support, tax incentive, enterprise core values, business opportunity, competitors, and compliance.

Based on the main lines of research identified in the literature review, we formulated the following research hypotheses:

(1) The corporate environmental responsibility behaviour of SMEs may be different by groups of EU countries, EU15 and EU-NMS13;

(2) The SMEs from EU are different in respect to their structural characteristics and motivations for providing green products and services, by groups of EU countries;

(3) SMEs motivations for providing green products and services (customers' demand, enterprise image, public support, tax incentive, enterprise core values, business opportunity, and competitors) may have different influences on CER by groups of EU countries; and

(4) Structural characteristics of SMEs may have different influences on CER by groups of EU countries. 


\section{Materials and Methods}

\subsection{Data}

Data used in the analysis come from the Flash Eurobarometer 381 Survey: SMEs, Resource Efficiency and Green Markets, made under the supervision of the European Commission. We performed a randomly conducted survey of small- and medium-sized enterprises (SMEs) from 38 countries (28 member states of the European Union and 10 non-EU states, such as Turkey, Norway, or United States of America). According to the definition recommended by the European Commission, the category micro-enterprise, SME, is made up of enterprises with under 250 employees and whose annual return does not exceed 50 million EUR and/or, the total annual balance of which does not exceed 43 million EUR [46]. SMEs are the main driver of the EU, comprising $99 \%$ of the total number of enterprises and covering $67 \%$ of the total number of jobs [47]. The study was conducted on a sample of 13,509 enterprises, of which 11,207 were from EU28 countries, 6303 were from the EU15 group of countries, and 4904 were from the EU-NMS13 group.

This study concentrated on SMEs providing green goods and services, as their business operation is directly correlated with environmental responsibility through the reduction of the quantity of pollutants released into the soil, water, and air. After limiting the database, using the criteria mentioned above, SMEs providing green goods and services, the size of the sample for EU28 comprised 3242 enterprises, 2009 enterprises for EU15 countries, and 1233 enterprises for EU-NMS13. The results shown in the next sub-sections were obtained after processing the data filtered by question Q17 (Does your company provide green products or services?) from the questionnaire of the Flash Eurobarometer 381 Survey. Data were processed using IBM SPSS and STATA statistical software.

Variables included in the analysis are shown in Table 1. The output variable is corporate environmental responsibility (CER), matching question Q1 in the din survey Eurobarometer 381 Survey: "Among these statements, which one applies the best to your company? Your company...", and it has five answer choices, which gradually present SMEs compliance with environmental legislation.

Explanatory variables of CER refer to a set of factors-enterprise features and motivations. We considered the following structural characteristics: Enterprise size (SCR10), age (SCR12), and sector (NACEb). Other SMEs characteristics reflect both the SMEs' experience acquired from undertaking resource efficiency actions (impact on production costs, and satisfaction of the return on investments) and the SMEs' background in selling green products or services.

The categories of the age variable were recoded to underline the features specific to former communist states included in the EU-NMS13 cluster. So, a threshold of 10 years was chosen, as a significant share of EU enterprises are less than ten years old, and the threshold of 29 years stands for the period that has passed since the collapse of the communist regime in countries grouped into EU-NMS13.

One important issue for the empirical analysis is related to the indicator used for the firm size. The firm size is considered by researchers as an important and fundamental firm characteristic. In many studies, a "size effect" was highlighted, meaning that the firm size affects the empirical results [48]. The measure used for the firm size may influence the sign and the significance of the coefficients both for the firm size and for other explanatory variables and also the value of the $\mathrm{R}$ squared corresponding to the estimated regression model.

In relation to the objective and the area of the research, one can consider several measures for the enterprise size: Number of employees, total sales, total or net assets, and market capitalization [49]. In the context of our research undertaken on the data collected from the Flash Eurobarometer 381 Survey: SMEs, Resource Efficiency and Green Markets, we considered it appropriate to analyze the two indicators used by the European Commision in the definition of SMEs and in the delimitation of SMEs categories (micro-, small-, and medium-sized): Number of employees and last year turnover. In order to test for the robustness of the model, we considered two indicators for the firm size: Number of employees (question SCR10) and last year turnover (question SCR14 recoded in four categories). 
Table 1. List of the variables.

\begin{tabular}{|c|c|}
\hline Variables (Flash Eurobarometer Questions) & Variables Categories \\
\hline \multirow{4}{*}{$\begin{array}{l}\text { Corporate Environmental Responsibility } \\
\text { (CER) (Among these statements, which one } \\
\text { applies the best to your company?) }\end{array}$} & $\begin{array}{l}\text { The company has difficulties in complying with environmental legislation } \\
\text { The company is complying with environmental legislation but does not } \\
\text { wish to go beyond these requirements }\end{array}$ \\
\hline & $\begin{array}{l}\text { The company is complying with environmental legislation and is } \\
\text { contemplating on doing more }\end{array}$ \\
\hline & $\begin{array}{l}\text { The company is going beyond the requirements of the environmental } \\
\text { legislation but environmental concerns are not one of its priorities }\end{array}$ \\
\hline & $\begin{array}{l}\text { The company is going beyond the requirements of the environmental } \\
\text { legislation and environmental concerns are one of its priorities }\end{array}$ \\
\hline $\begin{array}{l}\text { Motivations (What are the main reasons why your } \\
\text { company provides green products or services?) }\end{array}$ & $\begin{array}{l}\text { Demand from customers } \\
\text { Company's image } \\
\text { Public support (Subsidies/public support) } \\
\text { Tax incentive } \\
\text { Company's core values } \\
\text { Business opportunity (Creation of a competitive advantage/business } \\
\text { opportunity) } \\
\text { Competitors (Catching up with main competitors) } \\
\text { Compliance (Compliance with national, regional or local laws) } \\
\text { Others }\end{array}$ \\
\hline $\begin{array}{l}\text { Size of the enterprise (How many employees does } \\
\text { your company have?) }\end{array}$ & $\begin{array}{l}\text { Micro-enterprises ( } 1 \text { to } 9 \text { employees) } \\
\text { Small enterprises ( } 10 \text { to } 49 \text { employees) }^{\text {Medium-sized enterprises ( } 50 \text { to } 250 \text { employees) }}\end{array}$ \\
\hline $\begin{array}{l}\text { Size of the enterprise (What was your turnover } \\
\text { last year?) }\end{array}$ & $\begin{array}{l}\text { Micro-enterprises (Less than } 2 \text { million euros) }^{a} \\
\text { Small enterprises (More than } 2 \text { to } 10 \text { million euros) } \\
\text { Medium-sized enterprises (More than } 10 \text { to } 50 \text { million euros) } \\
\text { Large enterprises (More than } 50 \text { million euros) }\end{array}$ \\
\hline $\begin{array}{l}\text { Age (How long has your company been in } \\
\text { business) }\end{array}$ & $\begin{array}{l}1-9 \text { years }^{\text {a }} \\
10-29 \text { years } \\
30 \text { years and more }\end{array}$ \\
\hline Sector (NACE category) & $\begin{array}{l}\text { Manufacturing sector (NACE category C) } \\
\text { Retail (NACE category G) } \\
\text { Services (NACE categories } \mathrm{I} / \mathrm{J} / \mathrm{K} / \mathrm{H} / \mathrm{L} / \mathrm{M}) \\
\text { Industry (NACE categories } B / D / E / F)^{a}\end{array}$ \\
\hline $\begin{array}{l}\text { Production costs (What impact have the } \\
\text { undertaken resource efficiency actions had on the } \\
\text { production costs over the past two years?) }\end{array}$ & $\begin{array}{l}\text { It significantly decreased production costs (1) } \\
\text { It slightly decreased production costs }(2) \\
\text { It slightly increased production costs (3) } \\
\text { It significantly increased production costs (4) } \\
\text { It had no impact (5) }{ }^{a}\end{array}$ \\
\hline $\begin{array}{l}\text { Profitability (Overall, are you very satisfied, fairly } \\
\text { satisfied, fairly dissatisfied or very dissatisfied with } \\
\text { the return on the investments you have made on } \\
\text { resource efficiency?) }\end{array}$ & $\begin{array}{l}\text { Very satisfied (1) } \\
\text { Fairly satisfied (2) } \\
\text { Fairly dissatisfied (3) } \\
\text { Very dissatisfied (4) }\end{array}$ \\
\hline $\begin{array}{l}\text { Green commerce (For how long has your } \\
\text { company been selling green products or services?) }\end{array}$ & $\begin{array}{l}\text { For the last } 12 \text { months } \\
1-3 \text { years } \\
\text { More than } 3 \text { year }{ }^{a}\end{array}$ \\
\hline
\end{tabular}

Note: superscript letter $a$ denotes the control group (reference category) in the logit regression model.

The motivations taken into account by an enterprise when it provides green goods and services were included in question Q22 of the survey "What are the main reasons why your company provides green products or services?", with two compulsory answer choices.

From the categories of CER variables, we focused on the category "The company is complying with environmental legislation but does not wish to go beyond these requirements" as it is important to find paths for stimulating (developing actions for solving environmental problems) those who "do not wish to go beyond the requirements of environmental legislation. The production of green goods and services entails environmental responsibility and such enterprises may be motivated to do more than comply with legislation. 


\subsection{Methods}

To test the research hypotheses, we followed a three-step approach. First, we verified whether there were significant differences in the proportions of SMEs, from the two EU groups (EU15 and EU-NMS13), concerning the corporate environmental behaviour and the structural characteristics and motivations. At this stage, we used the Z-score test to test the differences between the proportions of the two populations. Second, we verified whether the factors, structural characteristics, and motivations of SMEs had a significant influence on CER, by groups of countries. For this purpose, we applied the binary logistic regression model. Third, we underlined the particular influence of the significant factors of CER by groups of countries. At this point, the nomogram was used.

For statistical analysis, the CER variable was transformed into a dummy variable, containing the categories: 1 -the company is complying with environmental legislation but does not wish to go beyond these requirements; and 0 -other. We also transformed the categories of the variable into dummy variables matching the reasons why an enterprise is providing green products or services, with code 1 -if the reason matching the category is viewed as important in the decision of an enterprise to provide green products or services, and 0 - for other situations.

Statistical analysis was conducted using various statistical procedures. The hypotheses regarding the existence of differences by groups of countries in terms of CER, its factors, characteristics, and motivations were verified using the $\mathrm{Z}$ test. The $\mathrm{Z}$-score test was used at this stage to compare the proportions of SMEs corresponding to the two EU groups of countries.

The statistical $\mathrm{Z}$ test used for comparing the proportions was calculated considering the following formula:

$$
z=\frac{\left(p_{1}-p_{2}\right)}{\sqrt{\frac{p_{1}\left(1-p_{1}\right)}{n_{1}}+\frac{p_{2}\left(1-p_{2}\right)}{n_{2}}}} \sim N(0,1) .
$$

If the calculated value of the statistical test was smaller than the critical value (equal to 1.96 when assuming a $5 \%$ risk), then we did not reject the assumption of the equality of proportions. Based on the $p$-value, calculated using the normal distribution, whether the differences between the two proportions was significant was determined. If the $p$-value was less than the significance level, then one may conclude that the proportion of SMEs from EU15 was significantly different from the proportion of SMEs from EU-NMS13. The identified differences may be used to explain the differences in the results of CER in terms of the characteristics and motivations of enterprises by clusters of countries.

In order to identify the influencing factors of CER, the Chi square association test was used. The variables displaying significant associations in terms of CER became explanatory variables in the regression model identified in the next step.

Next, the influence of drivers for CER was estimated. To estimate the environmental attitude of SMEs and to identify their determinant motivations and characteristics for their engagement in CER, we used binary logistic regression. A nomogram could be built in order to display the effect size of the influence of the CER explanatory factors. When using the binary logistic model, we estimated a logit equation, which is a linear function that models the logarithm of the probability of having the response, $Y=1$, to the predetermined baseline category, $Y=0$ [50].

In the logit equation, the dependent variable is the logarithm of odds (logit) or the odds:

$$
\begin{gathered}
\ln O d d s=\ln \left(\frac{P(Y=1 \mid X)}{P(Y=0 \mid X)}\right)=\beta_{0}+\beta_{1} X_{1}+\ldots+\beta_{k} X_{k}, \\
\text { Odds }=\left(\frac{P(Y=1 \mid X)}{P(Y=0 \mid X)}\right)=e^{\beta_{0}+\beta_{1} X_{1}+\ldots+\beta_{k} X_{k}},
\end{gathered}
$$

where $Y$ is the binary dependent variable; $X=\left(X_{1}, X_{2}, \ldots, X_{k}\right)$ is a set of explanatory variables, which may be continuous or categorical or both; and $\beta_{k}$ are the logit coefficients. The coefficient $\left(\beta_{k}\right)$ is the 
amount which the logit changes with one unit change in $X_{k}$, while the exponential function of the regression's coefficients $\left(e^{\beta}\right)$ is the amount to which the odds changes (odds ratio).

Our dependent variable $(Y)$ was a dichotomous outcome that reflects the CER of SMEs: The company is complying with environmental legislation but does not wish to go beyond the requirements (1) and The company wishes to go beyond environmental legislation (0). The explanatory variables were the reasons for which companies offer green products or services and the structural characteristics of companies. The method used to estimate the coefficients of the logistic regression was maximum likelihood estimation (MLE).

In order to evaluate the statistical significance of each coefficient, a Wald test was used. The quality of the logistic regression model was assessed using the likelihood ratio test. It provides the means for comparing the likelihood of the data under the full model against the likelihood of the data under the intercept model [51,52]. In order to validate the accuracy of the model, the area under the ROC (receiver operating characteristic) curve, namely AUC (area under the curve), was estimated. The information criteria, AIC and BIC, were also calculated.

We further assessed the potential endogeneity in the empirical study. There are two possible sources of endogeneity in the regression model of CER. First, there may be mutual causality between the dependent variable, CER, and the exploratory variables [53]. Previous studies on the motivations of SMEs for corporate environmental responsibility have studied the reverse influence of social and environmental responsibility on their motivation to produce green products and services [54-56]. A second source of endogeneity consists in unobservable variables that are correlated to both CER and motivations. If we do not explicitly control for these variables, the error term will absorb their effect. Therefore, the error term will be correlated with the motivations, causing biased and inconsistent estimates [57].

In order to mitigate the endogeneity problem, it is recommended that as many important control variables as possible are introduced in the model [57]. Following this approach, in our analysis, we controlled for the variables that correspond to SMEs' structural characteristics (size of the enterprise, age and sector) and to other variables that reflect both the SMEs' experience acquired from undertaking resource efficiency actions (impact on production costs, and satisfaction of the return on investments) and the SMEs' background in selling green products or services.

The choice for the control variables was based on the results of previous researches that have found significant influences of enterprise characteristics on CER [3,41], and significant influences of enterprise characteristics on the decision to produce green products and services [58].

The endogeneity problem in empirical corporate finance studies was addressed in two very recent papers. Coles and Li [59] estimated the role of observed and unobserved firm- and manager-specific characteristics in determining the primary features of corporate governance and performance. Moreover, Coles and Li [60] examined the relative importance of observed and unobserved firm- and manager-specific characteristics in determining the primary aspects of contract design and the effects of the related incentives for firm policy, risk, and performance.

The importance of the effects of explanatory variables for CER was graphically represented using the nomogram. Nomograms are widely used to indicate the probability of an event, primarily by reducing statistical predictive models to a single numerical estimate. The nomogram is a visualisation of a complex model equation, with the aim of representing the behaviour of a predictor in scales [61]. The nomogram is characterized by one scale corresponding to each variable, a score scale, a total score scale, and a probability scale. The length of the line corresponding to a given variable is correlated positively with the importance of the variable in the model. Therefore, the nomogram can be used as a descriptive or exploratory data analysis method [62].

Nomograms from multivariable logistic models are a user-friendly graphic interface to display the predicted probabilities of an event [63]. Nomograms are better than most alternative approaches, such as the provision of a full regression formula or a table with all regression coefficients [62]. 
The use of nomogram is simple, and it involves three steps. Firstly, on the scale of each variable, the value corresponding to a specific SME is read and then, using the score scale, the score for each variable is calculated. Secondly, by adding up the scores of all variables, the total score is calculated, and its value is identified on the total score scale. Finally, the probability of the event corresponding to the total score is read on the probability scale [64-66].

Kattan-style nomograms were generated in Stata using the nomolog program for binary logistic models [62].

\section{Results}

\subsection{Differences Concerning CER and Its Drivers for SMEs from EU15 and EU-NMS13 Countries}

Table 2 shows the distribution of SMEs providing green goods and services by CER for the EU15 and EU-NMS13, considering the responses for question Q1 from the Flash Eurobarometer 381 Survey questionnaire. The data in Table 2 show the percentages of SMEs by the categories of CER, in EU 15 and EU-NMS13, respectively. Also, we present the existence of significant differences between the proportions of the two groups of countries using the statistical test $\mathrm{Z}$. The results presented in Table 2 were obtained using the IBM SPSS 22.0 software. For each category of CER, we compared the proportion of SMEs from EU15 with the proportion of SMEs from EU-NMS13. When the two proportions do not differ significantly at the 0.05 significance level, similar letters are assigned to the data in Table 2. In addition, the existence of significant differences is marked by different letters.

Table 2. Distribution of SMEs by CER, in EU15 and EU-NMS13 countries (\%).

\begin{tabular}{lcc}
\hline \multicolumn{1}{c}{ Corporate Environmental Responsibility (CER) } & EU15 & EU-NMS13 \\
\hline $\begin{array}{l}\text { the company has difficulties in complying with } \\
\text { environmental legislation }\end{array}$ & $1.8^{\mathrm{a}}$ & $\mathbf{4 4 . 6}^{\mathrm{a}}$ \\
\hline $\begin{array}{l}\text { the company is complying with environmental legislation } \\
\text { but does not wish to go beyond these requirements }\end{array}$ & $\mathbf{3 6 . 2 ^ { \mathrm { a } }}$ & $28.0^{\mathrm{a}}$ \\
\hline $\begin{array}{l}\text { the company is complying with environmental legislation } \\
\text { and is contemplating doing more }\end{array}$ & $28.0^{\mathrm{a}}$ & $10.5^{\mathrm{a}}$ \\
\hline $\begin{array}{l}\text { the company is going beyond the requirements of the } \\
\text { environmental legislation, but environmental concerns are } \\
\text { not one of its priorities }\end{array}$ & $10.8^{\mathrm{a}}$ & $\mathbf{1 5 . \mathbf { 1 } ^ { \mathbf { b } }}$ \\
\hline $\begin{array}{l}\text { the company is going beyond the requirements of the } \\
\text { environmental legislation and environmental concerns are } \\
\text { one of its priorities }\end{array}$ & $\mathbf{2 3 . 2 ^ { \mathbf { a } }}$ & $\mathbf{1 0 0}$ \\
\hline
\end{tabular}

Notes: Each superscript letter denotes a subset of EU groups whose column proportions do not differ significantly from each other at the 0.05 level.

It could be noted that the highest percentage in both groups of countries appears for enterprises complying with environmental legislation but not wishing to go beyond the requirements. At the same time, it was found that there are significant differences between the two groups of EU countries by specific categories of the CER variable. There is a significantly higher percentage of SMEs from EU-NMS13 (44.6\%) that are complying with environmental legislation but do not wish to go beyond these requirements compared to EU15 (36.2\%). Even more, the percentage of SMEs that are going beyond the requirements of the environmental legislation and, in which, environmental concerns are one of their priorities is significantly higher for EU15 countries (23.2\%) compared to EU-NMS13 (15.1\%). Overall, we obtained a significant value corresponding to the Chi-square independence test $\left(\chi^{2}=37.826\right)$ with four degrees of freedom, at the 0.01 level. Therefore, we can conclude that corporate environmental responsibility differs between the two groups of SMEs. 
Therefore, we can conclude that the corporate environmental responsibility behaviour of SMEs differs between the two groups of EU countries, EU15 and EU-NMS13. In conclusion, the first research hypothesis is confirmed.

The distributions of SMEs providing green goods and services in EU15 and EU-NMS13 are shown in Table 3. The variables of the motivations group are of the dummy type. This table shows only the percentage of category 1 ; the specified motivation is viewed as important in the decision adopted by an enterprise to provide green goods and services.

The data in Table 3 show the percentages of SMEs by motivations, enterprise characteristics, and other variables, in EU 15 and EU-NMS13, respectively. Also, we present the existence of significant differences between the proportions of the two groups of countries using the statistical $\mathrm{Z}$ test. The results presented in Table 3 were obtained using the IBM SPSS 22.0 software. For each variable's category, we compared the proportion of SMEs from EU15 with the proportion of SMEs from EU-NMS13. For motivations, we compared the affirmative proportion of SMEs from EU15 with the corresponding proportion of SMEs from EU-NMS13. We assigned similar letters to the proportions of the two groups of EU countries when the difference between proportions was not statistically significant at the 0.05 significance level. Also, the existence of significant differences is marked by different letters.

There are significant differences in the distributions of enterprises providing green goods and services for the two groups of countries. In terms of the structural characteristics of enterprises, there are differences in the enterprise age between the two groups of countries. Considering the SMEs' motivations for green products and services, it was found that, compared to the EU-NMS13 group, the enterprises from EU15 countries are much more motivated by the following drivers: Image, value of an enterprise, and business opportunity.

The enterprises of EU-NMS13 countries are much younger compared to the the SMEs from the EU15 group. It is seen in the much higher percentage of enterprises aged less than 30 years, and much lower percentage of enterprises aged over 30 years in the EU-NMS13 group compared to enterprises in the EU15 group. Another important result proves that the percentage of SMEs from the industry sector is significantly higher in the EU15 group than in the EU-MNS13 group.

Considering the distribution of SMEs by enterprise size, the results are different in relation to the measure considered for this characteristic. If the enterprise size is expressed by the number of employees, there are no significant differences between the two groups of countries. However, if the enterprise size is measured by the last year turnover there are significant differences in the distributions of SMEs between the two EU groups.

The impact of the undertaken resource efficiency actions on the production costs is significantly different between the two groups of countries. The percentage of SMEs that had a significant decrease or a slight decrease in their production costs is significantly higher in EU-NMS13 countries compared to the EU15 countries. There are also significant differences in the degree of satisfaction with the return on the investments made by SMEs on resource efficiency. The enterprises from EU15 are more satisfied with their profitability compared to enterprises from EU-NMS13. The SMEs from EU15 have a longer practice in selling green products or services compared to the EU-NMS13 group.

To conclude, we can underline that the SMEs from the EU are different in respect to their motivations for providing green products and services and to their structural characteristics, by groups of EU countries. Consequently, the second research hypothesis was validated. 
Table 3. Distributions of SMEs by motivations, structural characteristics, and other variables, in EU15 and EU-NMS13 countries (\%).

\begin{tabular}{|c|c|c|}
\hline Variables & EU15 & EU-NMS13 \\
\hline \multicolumn{3}{|l|}{ Motivations } \\
\hline Demand from customers * & $55.2^{\mathrm{a}}$ & $52.6^{\mathrm{a}}$ \\
\hline Company's image * & $36.9^{a}$ & $27.1^{b}$ \\
\hline Subsidies/Public support* & $4.3^{\mathrm{a}}$ & $4.9^{\mathrm{a}}$ \\
\hline Tax incentive * & $3.6^{\mathrm{a}}$ & $2.6^{\mathrm{a}}$ \\
\hline Company's values * & $35.1^{\mathrm{a}}$ & $27.3^{b}$ \\
\hline Business opportunity * & $32.8^{a}$ & $26.7^{b}$ \\
\hline Competitors * & $11.7^{\mathrm{a}}$ & $11.2^{\mathrm{a}}$ \\
\hline Compliance & $19.5^{\mathrm{a}}$ & $18.5^{\mathrm{a}}$ \\
\hline Others * & $4.6^{\mathrm{a}}$ & $5.5^{\mathrm{a}}$ \\
\hline \multicolumn{3}{|c|}{ Structural characteristics of enterprises } \\
\hline \multicolumn{3}{|c|}{ - Size of the enterprise: (a) Number of employees } \\
\hline - Micro- $[1 ; 10)$ employees & $41.3^{\mathrm{a}}$ & $42.9^{\mathrm{a}}$ \\
\hline - Small— $[10 ; 50)$ employees & $36.5^{\mathrm{a}}$ & $35^{\mathrm{a}}$ \\
\hline - Medium-[50; 250] employees & $22.2^{\mathrm{a}}$ & $22.1^{\mathrm{a}}$ \\
\hline TOTAL & 100 & 100 \\
\hline \multicolumn{3}{|l|}{ - Size of the enterprise: (b) Last year turnover } \\
\hline - Micro-< $<2$ mil. $€$ & $59.6^{a}$ & $75.0^{\mathrm{b}}$ \\
\hline - Small— $(2 ; 10]$ mil. $€$ & $22.4^{\mathrm{a}}$ & $18.1^{b}$ \\
\hline - Medium- $(10 ; 50]$ mil. $€$ & $14.0^{\mathrm{a}}$ & $5.9^{b}$ \\
\hline - Large $\longrightarrow 50$ mil. $€$ & $4.1^{\mathrm{a}}$ & $1.0^{\mathrm{b}}$ \\
\hline \multicolumn{3}{|l|}{ Age } \\
\hline - 1-9 years & $23.5^{\mathrm{a}}$ & $26.9^{b}$ \\
\hline • 10-29 years & $40.1^{\mathrm{a}}$ & $61.3^{b}$ \\
\hline - 30 years and more & $36.4^{\mathrm{a}}$ & $11.7^{\mathrm{b}}$ \\
\hline TOTAL & 100 & 100 \\
\hline \multicolumn{3}{|l|}{ Sector } \\
\hline - Manufacturing & $19.1^{\mathrm{a}}$ & $21.3^{\mathrm{a}}$ \\
\hline - Retail & $35.3^{\mathrm{a}}$ & $38^{\mathrm{a}}$ \\
\hline • Services & $21.2^{\mathrm{a}}$ & $19.7^{\mathrm{a}}$ \\
\hline - Industry & $24.5^{a}$ & $21^{b}$ \\
\hline TOTAL & 100 & 100 \\
\hline \multicolumn{3}{|l|}{ Other variables } \\
\hline \multicolumn{3}{|l|}{$\begin{array}{l}\text { Production costs } \\
\end{array}$} \\
\hline - Significantly decreased & $6.1^{a}$ & $8.5^{b}$ \\
\hline - Slightly decreased & $47.2^{\mathrm{a}}$ & $48.4^{\mathrm{a}}$ \\
\hline - Slightly increased & $19.2^{\mathrm{a}}$ & $16.8^{\mathrm{a}}$ \\
\hline - Significantly increased & $4.9^{\mathrm{a}}$ & $5.4^{\mathrm{a}}$ \\
\hline - No impact & $22.6^{\mathrm{a}}$ & $20.9^{a}$ \\
\hline TOTAL & 100 & 100 \\
\hline \multicolumn{3}{|l|}{ - Profitability } \\
\hline • Very satisfied & $18.6^{\mathrm{a}}$ & $12^{b}$ \\
\hline • Fairly satisfied & $70.1^{\mathrm{a}}$ & $69.5^{\mathrm{a}}$ \\
\hline - Fairly dissatisfied & $8.9^{\mathrm{a}}$ & $14.4^{\mathrm{b}}$ \\
\hline - Very dissatisfied & $2.4^{\mathrm{a}}$ & $4.1^{b}$ \\
\hline TOTAL & 100 & 100 \\
\hline \multicolumn{3}{|l|}{ • Green commerce } \\
\hline - For the last 12 months & $5.5^{\mathrm{a}}$ & $7.4^{b}$ \\
\hline - 1-3 years & $23.3^{\mathrm{a}}$ & $21.4^{\mathrm{a}}$ \\
\hline - More than 3 years & $71.2^{\mathrm{a}}$ & $71.2^{\mathrm{a}}$ \\
\hline TOTAL & 100 & 100 \\
\hline
\end{tabular}

Notes: Each superscript letter denotes a subset of EU groups whose column proportions do not differ significantly from each other at the 0.05 level; * the percentages correspond to the Yes category. 
4.2. Associations between CER and SMEs Motivations, Characteristics, and Other Variables, in EU15 and EU-NMS13 Countries

Table 4 shows separately the bivariate distributions for EU15 and EU-NMS13 countries, in percentage, for CER, the motivations of SMEs, their characteristics, and other variables, such as the results of resource efficiency actions and green commerce. Similar to the data presented in Table 3 , Table 4 shows only the percentage of category 1 -the mentioned motivation is viewed as important in the decision of an enterprise to provide green goods and services-for the dummy variables from the motivations group.

The data in Table 4 also include the results of the $\mathrm{Z}$ test, which was used to verify the significance of differences between the proportions of CER for each category of characteristics and motivations, respectively. The differences in the proportions were tested within each of the two EU groups of SMEs. The $p$-value matching the Chi-square test, verifying the association between CER and its drivers, is also included in Table 4.

For EU15 countries, the companies that are complying with environmental legislation but do not wish to go beyond these requirements are predominantly micro-enterprises operating in the retail sector. The type of other enterprises, namely, the companies wishing to go beyond compliance with legislation, are medium-sized enterprises, predominantly in the services sector, which are much more motivated by the company's image, company's core values, and business opportunities. For the EU-NMS13 group, it was found that companies that are complying with environmental legislation but do not wish to go beyond these requirements are also predominantly micro-sized companies operating in the retail sector motivated by the company's image and values of an enterprise.

Table 4. Associations between CER and the SMEs' motivations, structural characteristics, and other variables, for each group of EU countries.

\begin{tabular}{|c|c|c|c|c|}
\hline \multirow[b]{3}{*}{ Drivers for CER } & \multicolumn{2}{|c|}{ EU15 } & \multicolumn{2}{|c|}{ EU-NMS13 } \\
\hline & \multicolumn{2}{|c|}{ CER } & \multicolumn{2}{|c|}{ CER } \\
\hline & $\begin{array}{l}\text { Does not Wish to } \\
\text { Go Beyond... }\end{array}$ & $\begin{array}{c}\text { Does Wish to Go } \\
\text { Beyond ... }\end{array}$ & $\begin{array}{l}\text { Does not Wish to } \\
\text { Go Beyond ... }\end{array}$ & $\begin{array}{c}\text { Does Wish to Go } \\
\text { Beyond ... }\end{array}$ \\
\hline \multicolumn{5}{|l|}{ Motivations * } \\
\hline $\begin{array}{l}\text { Demand from customers } \\
\qquad \chi^{2} p \text {-value }\end{array}$ & \multicolumn{2}{|c|}{0.174} & \multicolumn{2}{|c|}{0.107} \\
\hline $\begin{array}{c}\text { Company's image } \\
\chi^{2} p \text {-value }\end{array}$ & \multicolumn{2}{|c|}{0.000} & \multicolumn{2}{|c|}{0.001} \\
\hline $\begin{array}{c}\text { Public support } \\
\chi^{2} p \text {-value }\end{array}$ & \multicolumn{2}{|c|}{0.106} & $4.7 \mathrm{a}$ & $5 \mathrm{a}$ \\
\hline $\begin{array}{c}\text { Tax incentive } \\
x^{2} p \text {-value }\end{array}$ & \multicolumn{2}{|c|}{0.732} & \multicolumn{2}{|c|}{1.000} \\
\hline $\begin{array}{c}\text { Company's values } \\
\chi^{2} p \text {-value }\end{array}$ & \multicolumn{2}{|c|}{0.000} & \multicolumn{2}{|c|}{0.000} \\
\hline $\begin{array}{l}\text { Business opportunity } \\
\chi^{2} p \text {-value }\end{array}$ & \multicolumn{2}{|c|}{0.015} & \multicolumn{2}{|c|}{0.090} \\
\hline $\begin{array}{l}\text { Competitors } \\
\chi^{2} p \text {-value }\end{array}$ & \multicolumn{2}{|c|}{0.612} & \multicolumn{2}{|c|}{0.542} \\
\hline $\begin{array}{c}\text { Compliance } \\
\chi^{2} p \text {-value }\end{array}$ & \multicolumn{2}{|c|}{0.557} & \multicolumn{2}{|c|}{0.160} \\
\hline $\begin{array}{l}\text { Other } \\
\chi^{2} p \text {-value }\end{array}$ & \multicolumn{2}{|c|}{0.044} & \multicolumn{2}{|c|}{0.103} \\
\hline
\end{tabular}


Table 4. Cont.

\begin{tabular}{|c|c|c|c|c|}
\hline \multirow[b]{3}{*}{ Drivers for CER } & \multicolumn{2}{|c|}{ EU15 } & \multicolumn{2}{|c|}{ EU-NMS13 } \\
\hline & \multicolumn{2}{|c|}{ CER } & \multicolumn{2}{|c|}{ CER } \\
\hline & $\begin{array}{l}\text { Does not Wish to } \\
\text { Go Beyond ... }\end{array}$ & $\begin{array}{l}\text { Does Wish to Go } \\
\text { Beyond ... }\end{array}$ & $\begin{array}{c}\text { Does not Wish to } \\
\text { Go Beyond ... }\end{array}$ & $\begin{array}{c}\text { Does Wish to Go } \\
\text { Beyond ... }\end{array}$ \\
\hline \multicolumn{5}{|l|}{$\begin{array}{c}\text { Structural characteristics of } \\
\text { enterprises }\end{array}$} \\
\hline \multicolumn{5}{|l|}{$\begin{array}{l}\text { Size of the enterprise: (a) } \\
\text { Number of employees }\end{array}$} \\
\hline $\begin{array}{l}\text { - Micro-[1; 10) employees } \\
\text { - Small- }[10 ; 50) \text { employees } \\
\text { - Medium-[50; 250] employees }\end{array}$ & $\begin{array}{l}50.1 \text { a } \\
35.5 \mathrm{a} \\
\mathbf{1 4 . 4} \mathrm{a}\end{array}$ & $\begin{array}{c}36.5 \mathrm{~b} \\
37 \mathrm{a} \\
26.5_{\mathrm{b}} \\
\end{array}$ & $\begin{array}{l}45.3 \mathrm{a} \\
36.8 \mathrm{a} \\
\mathbf{1 7 . 9} \mathrm{a}\end{array}$ & $\begin{array}{l}41.1_{\mathrm{a}} \\
33.6_{\mathrm{a}} \\
25.3_{\mathrm{b}}\end{array}$ \\
\hline$\chi^{2} p$-value & \multicolumn{2}{|c|}{0.000} & \multicolumn{2}{|c|}{0.009} \\
\hline \multicolumn{5}{|l|}{$\begin{array}{c}\text { Size of the enterprise: (b) Last } \\
\text { year turnover }\end{array}$} \\
\hline $\begin{array}{l}\text { - Micro-<2 mil. } € \\
\text { - Small— }(2 ; 10] \text { mil. } € \\
\text { - Medium- }(10 ; 50] \text { mil. } € \\
\text { - Large—>50 mil. } €\end{array}$ & $\begin{array}{l}55.1 \mathrm{a} \\
24.2_{\mathrm{a}} \\
15.4 \mathrm{a} \\
5.3_{\mathrm{a}}\end{array}$ & $\begin{array}{l}67.5_{b} \\
19.2_{b} \\
11.5_{b} \\
1.9_{b}\end{array}$ & $\begin{array}{l}72.1 \mathrm{a} \\
18.7 \mathrm{a} \\
8.2 \mathrm{a} \\
1.0 \mathrm{a}\end{array}$ & $\begin{array}{l}78.7_{\mathrm{b}} \\
17.3_{\mathrm{a}} \\
3.0_{\mathrm{b}} \\
1.1_{\mathrm{a}}\end{array}$ \\
\hline$\chi^{2} p$-value & \multicolumn{2}{|c|}{0.000} & \multicolumn{2}{|c|}{0.003} \\
\hline \multicolumn{5}{|l|}{ Age } \\
\hline $\begin{array}{l}\text { - } 1-9 \text { years } \\
\text { - } 10-29 \text { years } \\
\text { - } 30 \text { years and more }\end{array}$ & $\begin{array}{r}21.3 \mathrm{a} \\
41.1 \mathrm{a} \\
367.6 \mathrm{a} \\
\end{array}$ & $\begin{array}{l}24.7 \mathrm{a} \\
39.5 \mathrm{a} \\
35.8 \mathrm{a}\end{array}$ & $\begin{array}{l}29.3 \mathrm{a} \\
60.3 \mathrm{a} \\
10.4 \mathrm{a}\end{array}$ & $\begin{array}{l}25.1 \mathrm{a} \\
62.1 \mathrm{a} \\
12.7 \mathrm{a}\end{array}$ \\
\hline$x^{2} p$-value & \multicolumn{2}{|c|}{0.241} & \multicolumn{2}{|c|}{0.177} \\
\hline \multicolumn{5}{|l|}{ Sector } \\
\hline $\begin{array}{l}\text { - Manufacturing } \\
\text { - Retail } \\
\text { - Services } \\
\text { - Industry }\end{array}$ & $\begin{array}{c}17.7 \mathrm{a} \\
38.9 \mathrm{a} \\
17 \mathrm{a} \\
26.4 \mathrm{a}\end{array}$ & $\begin{array}{l}19.8 \mathrm{a} \\
33.3_{\mathrm{b}} \\
23.4_{\mathrm{b}} \\
23.4_{\mathrm{a}}\end{array}$ & $\begin{array}{l}20.8 \mathrm{a} \\
42.5 \mathrm{a} \\
18.2 \mathrm{a} \\
18.5 \mathrm{a}\end{array}$ & $\begin{array}{l}21.7 \mathrm{a} \\
34.5 \mathrm{~b} \\
20.9 \mathrm{a} \\
22.9 \mathrm{a}\end{array}$ \\
\hline$\chi^{2} p$-value & \multicolumn{2}{|c|}{0.001} & \multicolumn{2}{|c|}{0.027} \\
\hline \multicolumn{5}{|l|}{ Other variables } \\
\hline \multicolumn{5}{|l|}{ Production costs } \\
\hline $\begin{array}{l}\text { - Significantly decreased } \\
\text { - Slightly decreased } \\
\text { - Slightly increased } \\
\text { - Significantly increased } \\
\text { - No impact }\end{array}$ & $\begin{array}{c}7.1 \mathrm{a} \\
49.6 \mathrm{a} \\
19.5 \mathrm{a} \\
4.6 \mathrm{a} \\
19.2 \mathrm{a} \\
\end{array}$ & $\begin{array}{l}4.2_{\mathrm{b}} \\
42.9_{\mathrm{b}} \\
18.7_{\mathrm{a}} \\
5.4_{\mathrm{a}} \\
28.8_{\mathrm{b}}\end{array}$ & $\begin{array}{c}8.6 \mathrm{a} \\
50.3 \mathrm{a} \\
13.6 \mathrm{a} \\
7.1 \mathrm{a} \\
20.4 \mathrm{a}\end{array}$ & $\begin{array}{l}8.4_{\mathrm{a}} \\
45.9_{\mathrm{a}} \\
21.0_{\mathrm{b}} \\
3.1_{\mathrm{b}} \\
21.6_{\mathrm{a}}\end{array}$ \\
\hline$\chi^{2} p$-value & \multicolumn{2}{|c|}{0.000} & \multicolumn{2}{|c|}{0.002} \\
\hline \multicolumn{5}{|l|}{ Profitability } \\
\hline $\begin{array}{l}\text { - Very satisfied } \\
\text { - Fairly satisfied } \\
\text { - Fairly dissatisfied } \\
\text { - Very dissatisfied }\end{array}$ & $\begin{array}{c}20.4 \mathrm{a} \\
69.9 \mathrm{a} \\
7.9 \mathrm{a} \\
1.8 \mathrm{a} \\
\end{array}$ & $\begin{array}{l}15.1_{\mathbf{b}} \\
70.2_{\mathbf{a}} \\
11.0_{\mathbf{b}} \\
3.7_{\mathbf{b}}\end{array}$ & $\begin{array}{c}13.1 \mathrm{a} \\
70.4 \mathrm{a} \\
13.6 \mathrm{a} \\
2.9 \mathrm{a} \\
\end{array}$ & $\begin{array}{l}10.5 \mathrm{a} \\
68.3_{\mathrm{a}} \\
15.4_{\mathrm{a}} \\
\mathbf{5 . 8} \mathrm{b} \\
\end{array}$ \\
\hline$\chi^{2} p$-value & \multicolumn{2}{|c|}{0.001} & \multicolumn{2}{|c|}{0.058} \\
\hline \multicolumn{5}{|l|}{ Green commerce } \\
\hline $\begin{array}{l}\text { - For the last } 12 \text { months } \\
\text { - } 1 \text {-3 years } \\
\text { - More than } 3 \text { years }\end{array}$ & $\begin{array}{l}5.2 \mathrm{a} \\
23.1 \mathrm{a} \\
71.7 \mathrm{a} \\
\end{array}$ & $\begin{array}{r}6.1 \mathrm{a} \\
23.7 \mathrm{a} \\
70.3 \mathrm{a} \\
\end{array}$ & $\begin{array}{c}5.9 \mathrm{a} \\
19.8 \mathrm{a} \\
74.3 \mathrm{a} \\
\end{array}$ & $\begin{array}{l}9.5_{b} \\
23.4_{a} \\
67.1_{b}\end{array}$ \\
\hline$\chi^{2} p$-value & \multicolumn{2}{|c|}{0.655} & \multicolumn{2}{|c|}{0.010} \\
\hline
\end{tabular}

Notes: each subscript letter denotes a subset of EU groups whose column proportions do not differ significantly from each other at the 0.05 level; * the percentages for motivations correspond to the yes category for each answer variant of Q22. 
Considering the enterprise size measured by the number of employees, it is worthwhile to underline that the percentage of micro-enterprises that are complying with environmental legislation but do not wish to go beyond these requirements is significantly higher to the enterprises that wish to go beyond compliance with legislation. However, when considering the enterprise size measured by the last year turnover, the results are the opposite. Consequently, enterprises with a higher turnover are more willing to go beyond compliance with environmental legislation.

The discovered differences between enterprises wishing to go beyond compliance with legislation, located in the EU15 and EU-NMS13 countries, refer to the sector, which, for the EU15 group, is mainly the services sector, and the retail sector for the EU-NMS13 group, being mainly motivated by business opportunity, which is specific to enterprises in the EU15 countries.

As for the associations between CER and characteristics and motivations, it was observed that there are significant associations in both groups of countries between CER and the size of the enterprise, sector, company's image, core values of an enterprise, business opportunity, production costs, profitability, and green commerce.

\subsection{Econometric Model of CER for SMEs from EU15 and EU-NMS13 Countries}

In order to examine whether there are differences regarding the impact of the determinants of corporate environment responsibility between enterprises in the countries of EU15 and EU-NMS13, we performed distinct logit models for the sample of EU15 countries and the sample of EU-NMS13 countries. The logit models, used for explaining the CER of SMEs in relation to reasons and structural characteristics of enterprises by groups of countries, are presented in Tables 5 and 6 .

In the logit model, the dependent variable was a binary variable that defined the two groups of SMEs: (1) The group of SMEs that are not willing to go further than what the law provides for; and (0) the group of SMEs, for which environmental responsibility is a priority. The variable was defined with the aim of focusing on the SMEs' non-willingness to go beyond legal requirements. The explanatory variables describe the reasons why companies provide green products and services. Another group of factors refers to structural characteristics of an enterprise, the experience acquired from undertaking resource efficiency actions, and the SMEs' background in selling green products or services. The explanatory variables were categorical variables; therefore, the logistic regression model used binary variables, considering a reference category. Therefore, the coefficients of the binary variables allowed us to compare the odds of each category of one independent variable with its reference category. The reference categories for each explanatory variable are shown in Table 1.

In the first stage of estimating the model for CER, we included the drivers reflected by the motivations of SMEs for producing green products and services. In the next stages, we included the control variables.

In order to test for the robustness of the model, we considered two indicators for the firm size: The number of employees and last year turnover. We find that these two measures of firm size are appropriate from the perspective of the definition of the European Commision for SMEs and of the delimitation of SMEs categories (micro, small, and medium-sized). Therefore, we estimated two sets of regression models corresponding to the two scenarios depending on the measure for firm size (scenario a for number of employees and scenario $b$ for the last year turnover). The results obtained for the two sets of models measuring the firm size by the number of employees and the last year turnover, respectivly, by groups of countries, EU15 and EU-NMS13, are presented in Tables 5 and 6. The interpretation of the results was made in the context of the definitions given by the European Commision to the indicators used in the regression models.

In order to mitigate the endogeneity problem, we controlled for the variables that correspond to SMEs structural characteristics (size of the enterprise, age and sector) and to other variables that reflect both the SMEs' experience acquired from undertaking resource efficiency and the SMEs' background in selling green products or services. This approach for the endogeneity problem has been proposed in other studies, such as Li [57]. In the first stage of estimating the model for CER, we included the 
drivers reflected by the motivations of SMEs for producing green products and services. In the next stages, we included the control variables.

Table 5. The estimated coefficients of the binary logit model of CER for EU15.

\begin{tabular}{|c|c|c|c|c|c|c|c|}
\hline $\begin{array}{l}\text { Explanatory } \\
\text { Variables }\end{array}$ & M1 & M2 (a) & M3 (a) & M4 (a) & M2 (b) & M3 (b) & M4 (b) \\
\hline \multicolumn{8}{|l|}{ Motivations } \\
\hline $\begin{array}{l}\text { Demand from } \\
\text { customers }\end{array}$ & -0.013 & 0.008 & 0.001 & -0.113 & 0.043 & 0.029 & -0.047 \\
\hline Company's image & $-0.467 * * *$ & $-0.482 * * *$ & $-0.439 * * *$ & $-0.420 * * *$ & $-0.487 * * *$ & $-0.460^{* * *}$ & $-0.431 * * *$ \\
\hline Public support & $-0.486 * *$ & $-0.465 *$ & $-0.472 *$ & $-0.698 * *$ & -0.435 & -0.440 & $-0.707^{* *}$ \\
\hline Tax incentive & -0.149 & -0.199 & -0.234 & -0.496 & -0.237 & -0.277 & -0.406 \\
\hline Core values & $-0.751 * * *$ & $-0.764 * * *$ & $-0.784 * * *$ & $-0.727^{* * *}$ & $-0.792 * * *$ & $-0.806 * * *$ & $-0.737 * * *$ \\
\hline Business opportunity & $-0.330 * * *$ & $-0.274 * * *$ & $-0.288^{* * *}$ & $-0.306 * *$ & $-0.228 * *$ & $-0.238^{* *}$ & -0.214 * \\
\hline Competitors & -0.108 & -0.111 & -0.117 & -0.063 & 0.037 & 0.016 & 0.084 \\
\hline Compliance & -0.105 & -0.068 & -0.044 & 0.081 & -0.080 & -0.065 & 0.048 \\
\hline \multicolumn{8}{|l|}{ Control variables } \\
\hline \multicolumn{8}{|l|}{ Enterprise size } \\
\hline$[10,50)$ employees & & $-0.383^{* * *}$ & $-0.472^{* * *}$ & $-0.398^{* * *}$ & & & \\
\hline$[50,250)$ employees & & $-0.945^{* * *}$ & $-1.073 * * *$ & $-0.897 * * *$ & & & \\
\hline$(2,10]$ mil. $€$ & & & & & $-0.513^{* * *}$ & $-0.630 * * *$ & $-0.563^{* * *}$ \\
\hline$(10,50]$ mil. $€$ & & & & & $-0.515^{* * *}$ & $-0.618^{* * *}$ & $-0.478^{* * *}$ \\
\hline$>50$ mil. $€$ & & & & & $-1.211^{* * *}$ & $-1.324^{* * *}$ & $-1.494^{* * *}$ \\
\hline \multicolumn{8}{|l|}{ Age } \\
\hline $10-29$ years & & & $0.343^{* * *}$ & $0.461^{* * *}$ & & $0.333^{* *}$ & $0.468^{* * *}$ \\
\hline $\begin{array}{l}30 \text { years and more } \\
\text { Sector }\end{array}$ & & & $0.499 * * *$ & $0.513 * * *$ & & $0.433^{* * *}$ & $0.441^{* * *}$ \\
\hline Manufacturing & & & -0.134 & -0.114 & & -0.067 & -0.069 \\
\hline Retail & & & 0.037 & 0.116 & & 0.183 & 0.217 \\
\hline Services & & & $-0.347^{* *}$ & $-0.412 * *$ & & $-0.400 * *$ & $-0.415^{* *}$ \\
\hline \multicolumn{8}{|l|}{ Production costs } \\
\hline $\begin{array}{c}\text { Significantly } \\
\text { decreased }\end{array}$ & & & & $-0.779 * * *$ & & & $-0.888^{* * *}$ \\
\hline Slightly decreased & & & & $-0.420 * * *$ & & & $-0.512 * * *$ \\
\hline Slightly increased & & & & $-0.502 * * *$ & & & $-0.584 * * *$ \\
\hline $\begin{array}{l}\text { Significantly } \\
\text { increased } \\
\text { Profitability }\end{array}$ & & & & -0.416 & & & -0.335 \\
\hline Very satisfied & & & & $-0.880 * *$ & & & $-0.782 *$ \\
\hline Fairly satisfied & & & & $-0.620 *$ & & & -0.502 \\
\hline Fairly dissatisfied & & & & -0.357 & & & -0.300 \\
\hline $\begin{array}{l}\text { Green commerce } \\
\text { For the last } 12 \text { months }\end{array}$ & & & & 0080 & & & 0090 \\
\hline $\begin{array}{c}\text { For the last } 12 \text { months } \\
1-3 \text { years }\end{array}$ & & & & 0.229 * & & & 0.192 \\
\hline Constant & -0.019 & $0.287^{* *}$ & 0.099 & $0.870^{* *}$ & 0.161 & -0.059 & 0.656 \\
\hline$n$ & 2009 & 1998 & 1976 & 1566 & 1771 & 1760 & 1433 \\
\hline Likelihood ratio $\chi^{2}$ & $86.85^{* * *}$ & $138.39 * * *$ & $163.69^{* * *}$ & $151.74^{* * *}$ & $115.20 * * *$ & $142.58^{* * *}$ & $144.41^{* * *}$ \\
\hline Pseudo $R^{2}$ & 0.033 & 0.053 & 0.064 & 0.076 & 0.050 & 0.062 & 0.079 \\
\hline AIC & 2543.374 & 2482.614 & 2437.266 & 1893.202 & 2222.561 & 2190.765 & 1739.147 \\
\hline BIC & 2593.823 & 2544.213 & 2526.687 & 2027.109 & 2288.312 & 2283.807 & 1876.102 \\
\hline AUC (ROC) & 0.624 & 0.659 & 0.673 & 0.688 & 0.650 & 0.668 & 0.691 \\
\hline
\end{tabular}

Notes: ${ }^{*}, * *$, and ${ }^{* * *}$ show the statistical significance of the regression coefficient with a risk of $0.1,0.05$, and 0.01 , respectively. 
Table 6. The estimated coefficients of the binary logit model of CER for EU-NMS13.

\begin{tabular}{|c|c|c|c|c|c|c|c|}
\hline $\begin{array}{l}\text { Explanatory } \\
\text { Variables }\end{array}$ & M1 & M2 (a) & M3 (a) & M4 (a) & M2 (b) & M3 (b) & M4 (b) \\
\hline \multicolumn{8}{|l|}{ Motivations } \\
\hline $\begin{array}{l}\text { Demand from } \\
\text { customers }\end{array}$ & 0.030 & 0.045 & 0.040 & 0.089 & 0.023 & 0.028 & 0.187 \\
\hline Company's image & $-0.395^{* * *}$ & $-0.372 * * *$ & $-0.373^{* * *}$ & $-0.285 *$ & $-0.473^{* * *}$ & $-0.457^{* * *}$ & $-0.348^{* *}$ \\
\hline Public support & -0.140 & -0.085 & -0.047 & -0.030 & -0.096 & -0.042 & -0.091 \\
\hline Tax incentive & -0.012 & -0.090 & -0.126 & -0.059 & 0.054 & 0.020 & 0.132 \\
\hline $\begin{array}{c}\text { Company's core } \\
\text { values }\end{array}$ & $-0.662 * * *$ & $-0.671^{* * *}$ & $-0.675^{* * *}$ & $-0.740 * * *$ & $-0.587^{* * *}$ & $-0.585^{* * *}$ & $-0.632^{* * *}$ \\
\hline Business opportunity & $-0.289 * *$ & $-0.300^{* *}$ & $-0.278^{* *}$ & $-0.347^{* *}$ & -0.233 & -0.196 & -0.153 \\
\hline Competitors & 0.068 & 0.090 & 0.077 & 0.134 & 0.065 & 0.063 & 0.151 \\
\hline Compliance & $-0.309^{* *}$ & $-0.267^{*}$ & -0.228 & -0.301 & $-0.356^{* *}$ & -0.293 & -0.306 \\
\hline \multicolumn{8}{|l|}{ Control variables } \\
\hline \multicolumn{8}{|l|}{ Enterprise size } \\
\hline$[10,50)$ employees & & 0.044 & 0.107 & $0.356^{* *}$ & & & \\
\hline$[50,250)$ employees & & $-0.389 * *$ & -0.281 & -0.176 & & & \\
\hline$(2,10]$ mil. $€$ & & & & & -0.090 & -0.078 & -0.043 \\
\hline$(10,50]$ mil. $€$ & & & & & $-0.993 * * *$ & $-1.006^{* * *}$ & $-0.930 * * *$ \\
\hline$>50$ mil. $€$ & & & & & -0.238 & -0.317 & 0.246 \\
\hline Age & & & & & & & \\
\hline $10-29$ years & & & -0.216 & -0.171 & & -0.197 & -0.054 \\
\hline 30 years and more & & & -0.294 & -0.229 & & -0.250 & -0.067 \\
\hline \multicolumn{8}{|l|}{ Sector } \\
\hline Manufacturing & & & 0.176 & 0.176 & & 0.211 & 0.165 \\
\hline Retail & & & $0.359 * *$ & $0.983 *$ & & $0.457^{* * *}$ & 0.394 * \\
\hline Services & & & 0.039 & -0.043 & & 0.022 & -0.174 \\
\hline \multicolumn{8}{|l|}{ Production costs } \\
\hline $\begin{array}{c}\text { Significantly } \\
\text { decreased }\end{array}$ & & & & -0.073 & & & -0.055 \\
\hline Slightly decreased & & & & -0.057 & & & -0.115 \\
\hline Slightly increased & & & & 0.388 & & & 0.443 \\
\hline $\begin{array}{l}\text { Significantly } \\
\text { increased }\end{array}$ & & & & $-0.994^{* * *}$ & & & $-0.880 * *$ \\
\hline \multicolumn{8}{|l|}{ Profitability } \\
\hline Very satisfied & & & & $-1.166^{* * *}$ & & & $-1.337^{* * *}$ \\
\hline Fairly satisfied & & & & $-0.906 * *$ & & & $-0.923 * *$ \\
\hline Fairly dissatisfied & & & & $-0.942 * *$ & & & $-0.865^{* *}$ \\
\hline \multicolumn{8}{|l|}{ Green commerce } \\
\hline For the last 12 months & & & & $0.456^{*}$ & & & 0.458 \\
\hline $1-3$ years & & & & $0.465^{* * *}$ & & & $0.434^{* *}$ \\
\hline Constant & 0.122 & 0.180 & 0.113 & 0.728 & 0.214 & 0.104 & 0.699 \\
\hline$n$ & 1233 & 1218 & 1207 & 919 & 1063 & 1056 & 831 \\
\hline Likelihood ratio $\chi^{2}$ & $42.44^{* * *}$ & $50.77^{* * *}$ & $58.76^{* * *}$ & $85.14^{* * *}$ & $49.07 * * *$ & $59.53^{* * *}$ & $78.83^{* * *}$ \\
\hline Pseudo $R^{2}$ & 0.025 & 0.030 & 0.036 & 0.068 & 0.034 & 0.041 & 0.070 \\
\hline AIC & 1662.713 & 1639.179 & 1626.540 & 1218.360 & 1433.825 & 1423.330 & 1105.076 \\
\hline BIC & 1708.768 & 1695.334 & 1708.074 & 1338.942 & 1493.451 & 1507.688 & 1227.864 \\
\hline AUC (ROC) & 0.605 & 0.613 & 0.626 & 0.669 & 0.618 & 0.635 & 0.666 \\
\hline
\end{tabular}

Notes: ${ }^{*}, * *$, and ${ }^{* * *}$ show the statistical significance of the regression coefficient with a risk of $0.1,0.05$, and 0.01 , respectively.

The results of the logit model consist of the estimated coefficients, their standard error, and the degree of significance. The results for the goodness-of-fit of the models comprise the Chi-squared likelihood ratio test, the area under the ROC curve, and the information criteria, AIC and BIC.

For both EU samples, model M1 shows a clear endogeneity problem, caused by the simultaneity between the CER and motivations (both endogeneous) and by the bi-directional causality between 
the dependent variable CER and the independent variables considered in the model. In order to solve the endogeneity problem, we introduced control variables and found significant influences of CER drivers on the enterpises' behaviour related to complying with environmental legislation. For both groups of EU countries, the results obtained for the final model (M4) are similar to the results for the initial model (M1). It is noticeable that, with a few exceptions, the coefficients associated to the motivations for producing green products and services kept their sign and remained statistically significant. For the EU15 sample, the results show a change in the significance threshold for the effect of a business opportunity on CER, while the effect of public support on CER became insignificant. For the EU-NMS13 sample, the significance threshold of the company's image effect on CER changed, and the compliance effect became insignificant. Among the four estimated models, model M4 provided the highest values for the pseudo-R square and AUC (ROC) and the lowest values for the AIC and BIC criteria.

To capture the importance of the firm size measures, we compared the results of the models in scenario $a$ (size firm is measured by the number of employees) to the results of the models in scenario $b$ (size firm is measured by the last year turnover). The main findings are: (i) The coefficients of the firm size measures keep their sign and their statistical significance; these results are consistent with previous studies, such as Dang et al. [48], according to which "in most areas of corporate finance the coefficients of firm size measures are robust in sign and statistical significance"; (ii) the coefficients on regressors other than firm size conserved their sign, but their significance threshold changed (for EU15-business opportunity, and for EU-NMS13 — company image) or they lost their statistical significance (for EU15- public support, and for EU-NMS13—-business opportunity); therefore, the results are not robust; (iii) there are differences in coefficients' size for the firm size variable: The last year turnover variable displayed higher coefficients and exerted a stronger influence on CER, compared to the number of employees; this finding is supported by the variations in the pseudo- $R$ square, AUC (ROC), and information criteria values, which were improved in the case of scenario $b$ compared to the alternative scenario $a$. In conclusion, we can assert that by using different measures of firm size, the results are not robust, but this situation is very common in this area.

Considering the structural characteristics of an enterprise, it can be seen that the size of an enterprise and age are important factors for SMEs' attitudes towards environmental responsibility, mainly in the EU15 countries. The enterprise size, measured either by the number of employees or by the last year turnover, has an overall negative impact on the environmental attitude of SMEs in EU, and the effect of the size is more important in the case of the SMEs belonging to EU15 than SMEs from EU-NMS13. The logit coefficients show that the larger the enterprise, the lower the probability of not wanting to go beyond the legal requirements. Therefore, the larger SMEs have a higher will to go beyond environmental legislation. Our results are consistent with previous studies that have demonstrated that larger enterprises are more environmentally responsible. A positive and significant correlation was found between firm size and corporate environmental responsibility: Larger firms tend to be more environmentally responsible [67]. Compared to micro enterprises, it has been argued that medium-sized enterprises are most likely to improve their environmental performance without being required to by law [68]. One explanation of this result is that larger-sized SMEs are more capable of a strategic response in terms of issues, such as environmental management; they have more resources that can be assigned to support social and environmental activities, as they are more visible to the public than small firms are. Baumann-Pauly et al. [69] found that, compared to multinational companies, SMEs possess organizational characteristics that are favorable for promoting the internal implementation of CSR-related practices in core business functions but constrain external communication and reporting about CSR.

The impact of age is different for the two groups of countries. For the EU15, the coefficients were highly significant and positive, showing that the odds of not going beyond environmental legislation is higher for older enterprises. Our findings are consistent with Ferri and Pini [70], who found a higher probability for older firms in Italy to make green investments and thus become more 
environmentally responsible. For the EU-MNS13 sample, the coefficients for age were positive but not significant, underlying that SMEs with longer business experience are more willing to go beyond legal requirements for environmental responsibility. These differences in the coefficients of the logit models may be explained by the different profile of the SMEs from the two EU groups. In the EU15 sample, there is a higher percent of large (according to their turnover) and old SMEs, compared to the EU-NMS13 sample. Previous studies on other EU-NMS13 countries have identified that there were no significant differences in social responsibility actions related to the age of the enterprise [71].

The sector in which SMEs operate is significant for both groups of EU countries. For SMEs from EU15, the enterprises in the services sector have a higher willingness to go beyond environmental legislation than those in the industry sector. However, the SMEs from EU-NMS13 in services have a lower willingness than those in the industry sector, but the difference was not statistically significant. Moreover, in the EU-NMS13 group, the SMEs in retail have a lower compliance with going beyond legal requirements.

Regarding the reasons for providing green products and services, there are several causes that are fundamental for the decision of an enterprise to provide green products and services, both for EU15 and EU-NMS13 countries. The main driver for the decision of SMEs to promote environmental actions is given by an enterprise's core values. The SMEs that offer green products and services, as an effect of the core value of an enterprise, have a lower probability of not wanting to go beyond legal requirements compared to SMEs not emphasizing the role of core values. Other factors that support the environmental attitudes of SMEs are their image and business opportunity.

It should be noted that public support is a significant factor only for SMEs from the EU15 countries. Companies agreeing that public support plays an important role in SME's development of environmental practices have a lower probability of not intending to go further than he legal constraints.

The enterprises that are more satisfied with the return on the investments they have made on resource efficiency are more willing to go beyond legal requirements. The effect of profitability on CER is more evident for the SMEs sample from EU-NMS13 compared to the EU15 sample.

The impact of the resource efficiency actions on the production costs over the past two years has an influence on SMEs' environmental attitude. The enterprises from the EU15 sample that had undertaken resource efficiency actions and decreased production costs were found to be going beyond environmental legislation.

The SMEs that have a shorter practice in selling green goods or services have a higher probability of complying and not going beyond environmental legislation compared to the SMEs with a longer practice of green commerce. This effect is was manifested more for the EU-NMS13 sample.

The logit models for the two EU groups of countries were validated by performing the likelihood ratio test, which was significant for both models, and by calculating the AUC values, which were found to be superior to 0.6. When comparing the statistical indicators by groups of countries, it can be seen that the AIC and BIC criteria and the AUC value were better for the logit model estimated on EU15 data as compared to the logit model estimated on EU-NMS13 data.

The importance of explanatory variables for CER was graphically shown using the nomogram. Four nomograms were built, two for the SMEs from EU15, and another two for the EU-NMS13 SMEs. For each group of countries, the nomograms correspond to the two scenarios for the model estimation: Scenario (a) for the case when the enterprise size was measured by the number of employees, and scenario (b) for the case when the enterprise size was measured by the last year turnover. The diagrams are presented in Figure 1 for EU15 enterprises and in Figure 2 for EU-NMS13 enterprises. In the nomogram construction, only the explanatory variables with an important influence on the environmental attitude of SMEs were kept. 


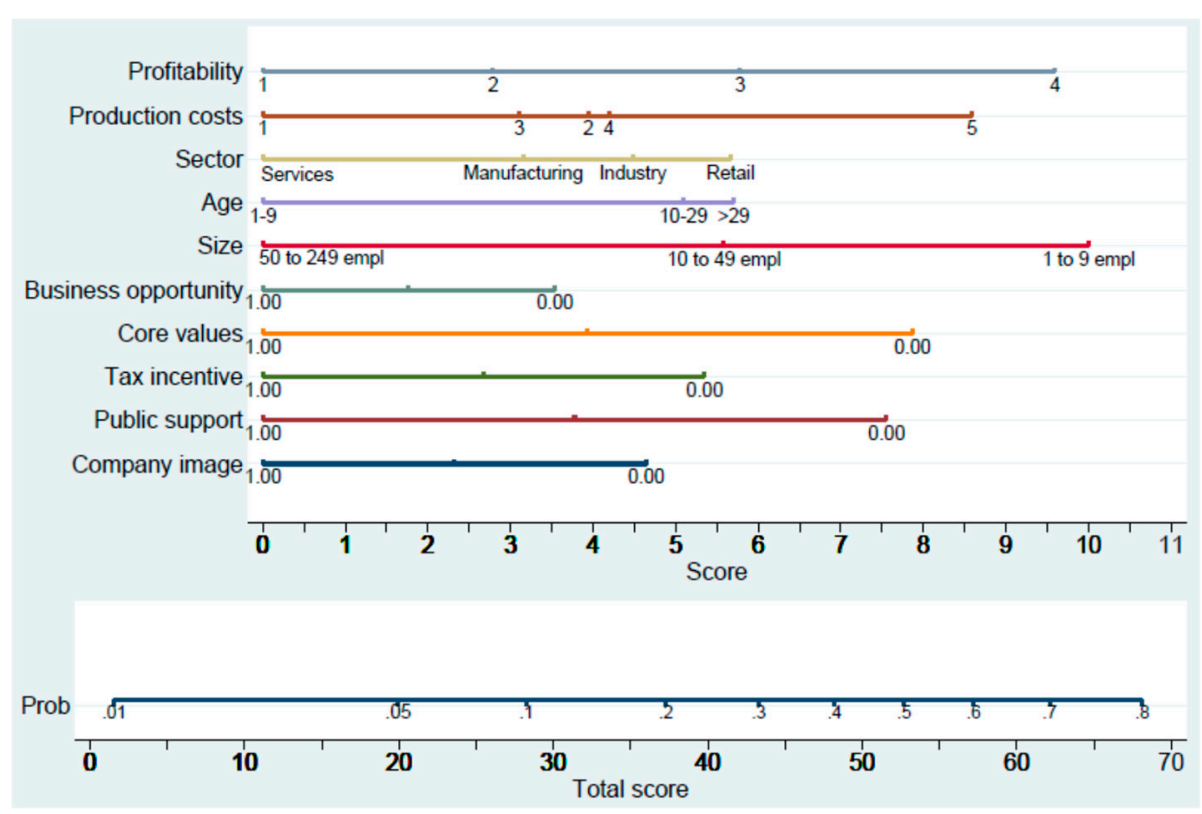

(a)

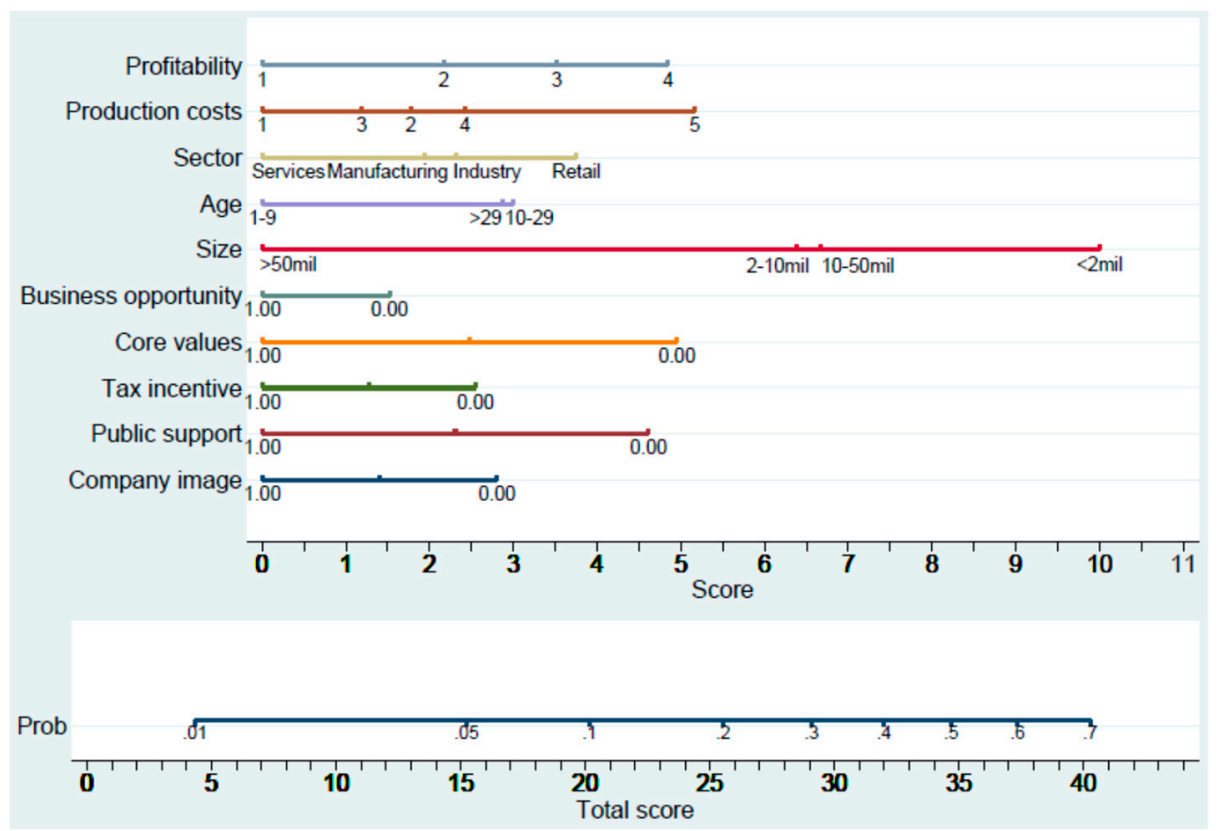

(b)

Figure 1. Nomogram of the importance of the effect of CER drivers for SMEs from EU15 countries; scenarios (a) and (b).

The diagrams in Figure 1 show that, among the reasons for providing green services and products, the most important drivers for explaining CER in EU15 countries are the core values of an enterprise and the public support. It can be noticed from both scenarios that enterprise size is an important factor of CER. 


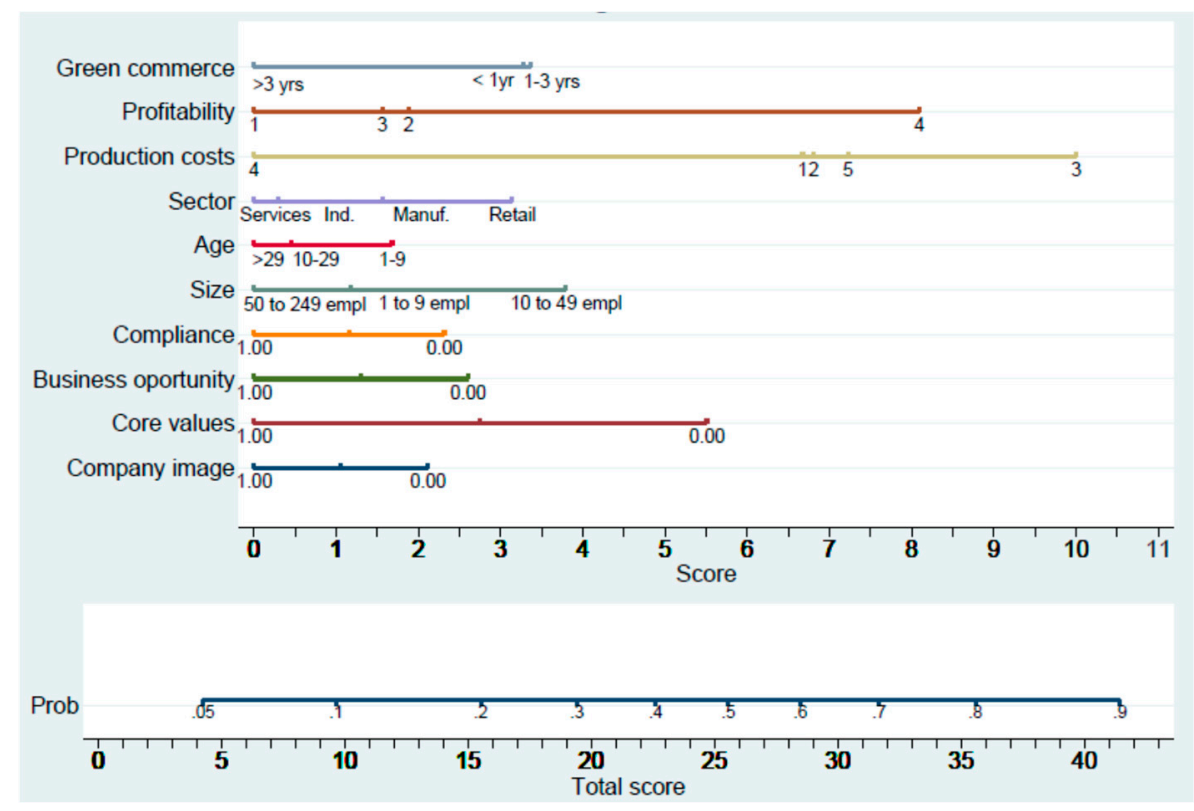

(a)

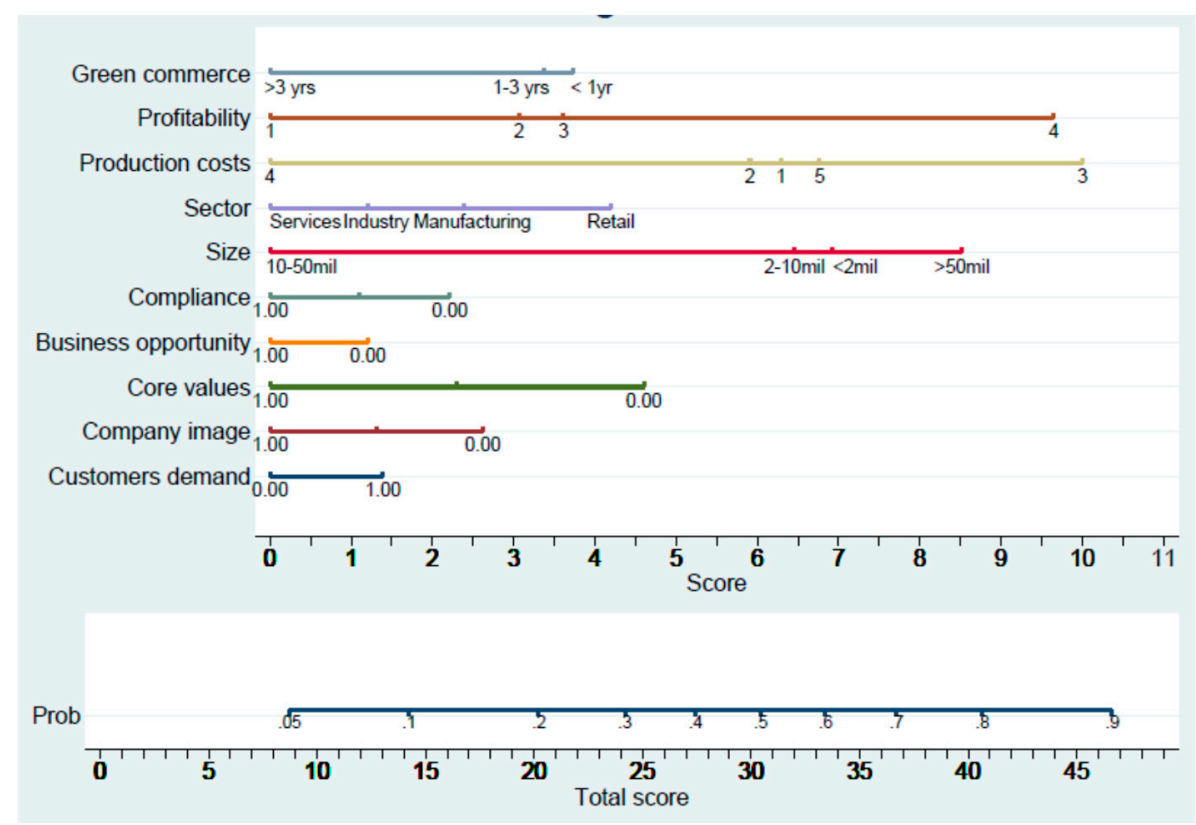

(b)

Figure 2. Nomogram of the importance of the effect of CER drivers for SMEs from EU-NMS13 countries; scenarios (a) and (b).

For both groups of countries, the enterprise size measured by the last year turnover has a higher importance in explaining CER compared to the meaure by the number of employees.

Moreover, the nomograms in Figures 1 and 2 underline the importance of the production costs and profitability on corporate environment responsibility. We should also note on the graph that the lines matching the two variables are the longest for EU-NMS13. Also, it was found that the most important reason for providing green products and services in the EU-NMS13 group is the company's core values.

In conclusion, we can emphasize that the factors of influence on CER have different effects on the environmental behaviour of SMEs, by groups of EU countries. Consequenlty, the third and the fourth 
hypotheses were validated. Therefore, it is necessary that SMEs should adopt the best practices of CER according to their structural characteristics and motivation for providing green products and services.

\section{Discussion and Conclusions}

This study aimed to test if there are significant differences between SMEs from EU15 and EU-NMS13 countries in adopting corporate environmental responsibility behaviour. To the best of our knowledge, this study is the first study investigating the difference in CER behaviour of green SMEs between the two groups of EU countries. Our main findings highlight the factors that drive the SMEs in the European Union to comply with the environmental legislation and become more environmentally responsible. Additionally, we suggest the use of a nomogram, which could become a relevant graphic tool to underline the importance of determinant factors' effects on the expected result. The increased environmental awareness of stakeholders leads an enterprise towards higher openness towards environmental issues. By supporting environmental protection, stakeholders promote sustainable development of an enterprise.

Our study fills a gap in the literature regarding the corporate environmental responsibility of SMEs comparing two groups of EU countries: Developed EU countries and developing EU countries. Furthermore, our results bring valuable information on the main drivers that support the pro-environmental behaviour of SMEs from the two EU groups.

The results show that in EU15 countries, there is a higher percentage of SMEs that go beyond the requirements of the environmental legislation, and for which environmental concerns are one of their priorities compared to SMEs in EU-NMS13 countries. Moreover, there is a higher percentage of SMEs in EU-NMS13 countries complying with the environmental legislation but not wishing to go beyond legal requirements (44.6\%) compared to EU15 (36.2\%). The explanation of such differences in CER between the two groups of countries may reside in the political, economic, historical, and cultural backgrounds of these societies [4]. Companies in Central and Eastern European countries adopt CER mainly to protect brands and keep their "licence to operate" by having society's approval for their activities [72,73]. The main reasons for refraining from setting up CER programs are fear of increased costs, lack of time and human resources, lack of motivation, and insufficient knowledge on how to set up and apply such a strategy. In a research consortium from 10 Central and Eastern European countries and two western European countries (Germany and Austria), Horvath et al. [68] used sustainability reporting to explain the differences between the two sub-samples. Another study on CER stresses that customer behaviour is the most important barrier in spreading social and environment responsibility in Central and Eastern European countries [18]. Therefore, in countries, such as Hungary, Romania, Poland, and Slovakia, customers are viewed as essential in putting pressure on companies in such matters as green and social inventions, product quality, resource efficiency, and green production.

In line with previous studies, such as Aguado and Holl [41], Saez-Martinez et al. [3], or Demirel et al. [44], our findings show that structural characteristics of SMEs are important in explaining differences in CER behaviour. However, the impact of these factors is different for the two groups of countries. The larger SMEs have a higher affinity towards a pro-environmental behaviour. For EU15, SMEs' age has a significant influence on the environmental attitude. In EU-NMS13, the share of younger enterprises is higher, which could explain the different attitude towards CER in these countries compared to EU15. The EU15 enterprises are older, and as they age, the probability is higher that these would be reluctant to do more for environmental protection.

In addition, the sector of SMEs has a significant influence on the environmental attitude. For EU15, there is higher probability that enterprises operating in services would support environmental protection compared to industrial enterprises. For SMEs operating in services in EU-NMS13 countries, awareness of the importance of CER should be increased.

Other variables, such as profitability and production costs variation, as well as the green practice, also have a significant effect on CER. For the EU-NMS13 enterprises, the higher the practice in selling green goods or services, the higher the probability of going beyond the environmental legislation. 
The distinct estimations of the logit models for the two groups of countries highlight both similarities and disparities regarding the drivers of CER. SMEs from both groups of countries are driven in their environmental attitude by such reasons as core values, image of an enterprise, and business opportunity. Therefore, it is important to notice that SMEs from both groups of countries are engaged in CER mainly due to internal drivers. Furthermore, the market demand for green products and services is a real driver for SMEs' commitment to CER in the EU15. For EU-NMS 13 countries, there is a need to stimulate innovation and creativity in order to create more business opportunities for SMEs. However, tax incentives play an insignificant role in predicting the SMEs environmental attitude both in EU15 and EU-NMS13 countries.

This study may have several implications for the general public, entrepreneurs, and policy makers in EU15 and EU-MNS13 countries. The SMEs, providing green products and services, need to be supported in their initiatives to engage in environmentally responsible activities by their customers, the general public, and by policies targeted at creating a pro-environmental behaviour through taxes. In the case of SMEs in EU-NMS13 countries, it is necessary to develop policies encouraging entrepreneurs to create and innovate in terms of business opportunities. In these countries, there is a higher need for entrepreneurs to be shown the benefits of environmentally friendly management practices and consequently of undertaking green initiatives. This also implies that communities and governments should implement strict regulations and other political incentives to push CER practices of SMEs [17]. Moreover, raising the awareness of CER can be beneficial and may be synchronized with business interests [18]. The findings on the increasing importance of the company's reputation may help both company managers and policy makers in building up their activities for stimulating CER practices.

The gap that exists between the practices of SMEs from the two EU groups of countries may be reduced by a clearer understanding of the best practices of the developed EU states and of all the benefits of sustainable development [74].

Future lines of research could be related to extending the comparative study using a more complex sample comprising SMEs from different geographical regions in the world. Also, the methodological approach could be further developed by using a multinomial logit model to compare various environmental attitudes of SMEs.

Author Contributions: All authors contributed equally to the research presented in this paper and to the preparation of the final manuscript.

Funding: This research received no external funding.

Conflicts of Interest: The authors declare no conflict of interest.

\section{References}

1. Marlin, A.T.; Marlin, J.T. A brief history of social reporting. Bus. Respect 2003, 51. Available online: mallenbaker.net/csr/CSRfiles/page.php?Story_ID=857 (accessed on 12 July 2019).

2. Mason, M. The New Accountability: Environmental Responsibility across Borders; Earthscan: London, UK, 2005.

3. Sáez-Martínez, F.J.; Díaz-García, C.; González-Moreno, A. Factors Promoting Environmental Responsibility in European SMEs: The Effect on Performance. Sustainability 2016, 8, 898. [CrossRef]

4. Kopp, H. Corporate Social Responsibility in Modern Central and Eastern Europe. In Book Responsible Investment Banking; Springer International Publishing: Cham, Switzerland, 2015. [CrossRef]

5. Pislaru, M.; Herghiligiu, I.V.; Robu, I.B. Corporate sustainable performance assessment based on fuzzy logic. J. Clean. Prod. 2019, 223, 998-1013. [CrossRef]

6. Islam, S.M.M. Corporate Reporting Concept and the Emerge of Nonfinancial Information Reporting: A Literature Review. Res. J. Financ. Account. 2017, 8, 49-59.

7. Brundtland, G.H.; United Nations WCED. Our Common Future; Oxford University Press: Oxford, UK, 1987.

8. Căutisanu, C.; Asandului, L.; Borza, M.; Turturean, C. Quantitative Approach to Circular Economy in the OECD Countries. Amfiteatru Econ. 2018, 20, 182-196. [CrossRef]

9. Carroll, A.B. The Pyramid of Corporate Social Responsibility: Toward the Morai Management of Organizational Stakeholders. Bus. Horiz. 1991, 34, 40-48. [CrossRef] 
10. European Commission. A Renewed EU Strategy 2011-14 for Corporate Social Responsibility, com/2011/0681 Final. Available online: https://eur-lex.europa.eu/legal-content/EN/TXT/?uri=CELEX:52011 (accessed on 10 July 2019).

11. Jennifer, K.L.; Mark, A. Motivations for corporate social and environmental responsibility: A case study of Scandinavian Airlines. J. Int. Manag. 2008, 14, 377-390.

12. Vogel, D. The Market for Virtue: The Potential and Limits of Corporate Social Responsibility; Brookings: Washington, DC, USA, 2005.

13. Dummett, K. Drivers for Corporate Environmental Responsibility. Environ. Dev. Sustain. 2006, 8, 375-389. [CrossRef]

14. Huckle, G. Environmental Responsibility and Profitability in the Industrial and Mining Sector; University of Witwatersrand: Johannesburg, South Africa, 1995.

15. Gunningham, N. Shaping corporate environmental performance: A review. Environ. Policy Gov. 2009, 19, 215-231. [CrossRef]

16. Orlitzky, M.; Siegel, S.D.; Waldman, D.A. Strategic Corporate Social Responsibility and Environmental Sustainability. Bus. Soc. 2011, 50, 6-27. [CrossRef]

17. Holtbrügge, D.; Dögl, C. How international is corporate environmental responsibility? A literature review. J. Int. Manag. 2012, 18, 180-195. [CrossRef]

18. Csafor, H. Corporate social responsibility in Central and Eastern Europe. In Periodica Oeconomica-Studies of Economic Sciences, Regional Development and Competitiveness; Carmona, M., Szlavik, J., Zam, E., Eds.; University of Paris-Sorbonne IV and Eszterházy Károly College: Eger, Hungary, 2008; pp. 115-127.

19. Fijałkowska, J.; Zyznarska-Dworczak, B.; Garsztka, P. Corporate Social-Environmental Performance versus Financial Performance of Banks in Central and Eastern European Countries. Sustainability 2018, 10, 772. [CrossRef]

20. Chirilă, V.; Chirilă, C. Statistical analysis of the technological changes and of the business cycles in the Central and Eastern European Countries. In Proceedings of the 7th International Conference Management of Technological Changes-MTC 2011, Alexandroupolis, Greece, 1-3 September 2011; Costache, R., Ed.; Democritus University of Thrace: Komotini, Greece, 2011; pp. 361-364.

21. Giroud, X.; Mueller, H. Corporate governance, product market competition, and equity prices. J. Financ. 2011, 66, 563-600. [CrossRef]

22. Hong, B.; Li, Z.; Minor, D. Corporate Governance and Executive Compensation for Corporate Social Responsibility. J. Bus. Ethics 2016, 136, 199-213. [CrossRef]

23. Ikram, A.; Li, Z.; Minor, D. CSR-Contingent Executive Compensation Contracts. J. Bank. Financ. 2019, Forthcoming. 105655. [CrossRef]

24. Li, Z.; Thibodeau, C. CSR-Contingent Executive Compensation Incentive and Earnings Management. Sustainability 2019, 11, 3421. [CrossRef]

25. Henriques, I.; Sadorsky, P. The Determinants of an Environmentally Responsive Firm: An Empirical Approach. J. Environ. Econ. Manag. 1996, 30, 381-395. [CrossRef]

26. Rashid, N.R.N.A.; Rahman, N.I.A.; Khalid, S.A. Environmental Corporate Social Responsibility (ECSR) as a Strategic Marketing Initiatives. Procedia Soc. Behav. Sci. 2014, 130, 499-508. [CrossRef]

27. Jahanshahi, A.A.; Brem, A. Antecedents of Corporate Environmental Commitments: The Role of Customers. Int. J. Environ. Res. Public Health 2018, 15, 1191. [CrossRef]

28. Chen, Y.S. The Drivers of Green Brand Equity: Green Brand Image, Green Satisfaction, and Green Trust. J. Bus. Ethics 2010, 93, 307-319. [CrossRef]

29. Cai, W.; Li, G. The drivers of eco-innovation and its impact on performance: Evidence from China. J. Clean. Prod. 2018, 176, 110-118. [CrossRef]

30. Gilley, M.K.; Worell, D.L.; Davidson, W.N., III; El-Jelly, A. Corporate Environmental Initiatives and Anticipated Firm Performance: The Differential Effects of Process-Driven Versus Product-Driven Greening Initiatives. J. Manag. 2000, 26, 1199-1216.

31. Nuta, F.M.; Nuta, A.C. The Impact of Financial Performance upon the Social Responsibility of Romanian SMEs - Point of View. Acta Universitatis Danubius OEconomica 2012, 4, 25-31.

32. Bazilier, R.; Hatte, S.; Vauday, J. Are environmentally responsible firms less vulnerable when investing abroad? The role of reputation. J. Comp. Econ. 2017, 45, 520-543. [CrossRef] 
33. Gănescu, C.; Dindire, L. Corporate environmental responsibility-A key determinant of corporate reputation. Comput. Methods Soc. Sci. 2014, 2, 48-53.

34. Sekulic, V.; Pavlovic, M. Corporate Social Responsibility in relations with social community: Determinants, development, management aspects. Ekonomika 2018, 64, 59-69. [CrossRef]

35. Schaefer, A. Corporate sustainability-Integrating environmental and social concerns? Corp. Soc. Responsib. Environ. Manag. 2004, 11, 179-187. [CrossRef]

36. Chen, J.; Zhang, F.; Liu, L.; Zhu, L. Does environmental responsibility matter in cross-sector partnership formation? A legitimacy perspective. J. Environ. Manag. 2019, 231, 612-621.

37. Bansal, P.; Roth, K. Why Companies Go Green: A Model of Ecological Responsiveness. Acad. Manag. J. 2000, 43, 717-736.

38. Annandale, D.; Taplin, R. The Determinants of Mining Company Response to Environmental Approvals Regulation: A Report of Australian Research. J. Environ. Plan. Manag. 2003, 46, 887-909. [CrossRef]

39. Bichta, C. Corporate Socially Responsible (CSR) practices in the context of Greek industry. Corp. Soc. Responsib. Environ. Manag. 2003, 10, 12-24. [CrossRef]

40. Nikolau, I.E.; Evangelinos, K.I. A SWOT analysis of environmental management practices in Greek Mining and Mineral Industry. Resour. Policy 2010, 35, 226-234. [CrossRef]

41. Aguado, E.; Holl, A. Differences of Corporate Environmental Responsibility in Small and Medium Enterprises: Spain and Norway. Sustainability 2018, 10, 1877. [CrossRef]

42. Doran, J.; Ryan, G. The Importance of the Diverse Drivers and Types of Environmental Innovation for Firm Performance. Bus. Strategy Environ. 2016, 25, 665-667. [CrossRef]

43. Li, D.; Cao, C.; Zhang, L.; Chen, X.; Ren, S.; Zhao, Y. Effects of corporate environmental responsibility on financial performance: The moderating role of government regulation and organizational slack. J. Clean. Prod. 2017, 166, 1323-1334. [CrossRef]

44. Demirel, P.; Iatridis, K.; Kesidou, E. The impact of regulatory complexity upon self-regulation: Evidence from the adoption and certification of environmental management systems. J. Environ. Manag. 2017, 207, 80-91. [CrossRef]

45. Core, J.; Guay, W. The use of equity grants to manage optimal equity incentive levels. J. Account. Econ. 1999, 28, 151-184. [CrossRef]

46. User Guide to the SME Definition, European Commission. 2015. Available online: https://publications.europa. eu/en/publications-detail/-/publication/79c0ce87-f4dc-11e6-8a35-01aa75ed71a1 (accessed on 8 July 2019).

47. European Commission. SMEs, Ressource Efficiency and Green Market. Report; Flash Eurobarometer 381-TNS Political \& Social. 2013. Available online: https://ec.europa.eu/public_opinion/flash/fl_381_en.pdf (accessed on 8 July 2019).

48. Dang, C.; Li, Z.; Yang, C. Measuring Firm Size in Empirical Corporate Finance. J. Bank. Financ. 2018, 86, 159-176. [CrossRef]

49. Beck, T.; Demirgüç-Kunt, A.; Maksimovic, V. The influence of financial and legal institutions on firm size. J. Bank. Financ. 2006, 30, 2995-3015. [CrossRef]

50. Agresti, A. Categorical Data Analysis, 2nd ed.; Wiley-Interscience: New York, NY, USA, 2002.

51. Kleinbaum, D.; Klein, M. Logistic Regression: A Self-Learning Text, 3rd ed.; Springer: New York, NY, USA, 2010.

52. Hosmer, D.; Lemeshow, S. Applied Logistic Regression; Wiley: New York, NY, USA, 2000.

53. Jiang, Y.; Xue, X.; Xue, W. Proactive Corporate Environmental Responsibility and Financial Performance: Evidence from Chinese Energy Enterprises. Sustainability 2018, 10, 964. [CrossRef]

54. Abbaslu, L.; Zare, M.; Darabi, S.A.; Akhbarieh, M.; Beinabaj, M.H. The Impact of Social Responsibility on the Green Supply Chain: The study of Shiraz Industrial Town Companies. Int. J. Oper. Logist. Manag. 2015, 4, 204-213.

55. Babiak, K.; Trendafilova, S. CSR and Environmental Responsibility: Motives and Pressures to Adopt Green Management Practices. Corp.Soc. Responsib. Environ. Manag. 2011, 18, 11-24. [CrossRef]

56. Forman, M.; Jørgensen, M.S. Organising environmental supply chain management-experience from a sector with frequent product shifts and complex product chains: The case of the Danish textile sector. Greener Manag. Int. 2004, 45, 43-62. [CrossRef]

57. Li, F. Endogeneity in CEO power: A survey and experiment. Investig. Anal. J. 2016, 45, 149-162. [CrossRef]

58. Uyar, A.; Kilic, M.; Bayyurt, N. Association between firm characteristics and corporate voluntary disclosure: Evidence from Turkish listed companies. Intang. Cap. 2013, 9, 1080-1112. [CrossRef] 
59. Coles, J.L.; Li, Z. Managerial Attributes, Incentives, and Performance. 2019. Available online: https: //ssrn.com/abstract=1680484 (accessed on 7 October 2019).

60. Coles, J.L.; Li, Z. An Empirical Assessment of Empirical Corporate Finance. 2019. Available online: https://ssrn.com/abstract=1787143 (accessed on 8 October 2019).

61. Kattan, M.W.; Marasco, J. What is a real nomogram? Semin. Oncol. 2010, 37, 23-26. [CrossRef]

62. Zlotnik, A.; Abraira, V. A general-purpose nomogram generator for predictive logistic regression models. Stata J. 2015, 15, 537-546. [CrossRef]

63. Yang, D. Build Prognostic Nomograms for Risk Assessment Using SAS, Paper 264-2013. In Proceedings of the SAS Global Forum 2013, San Francisco, CA, USA, 28 April-1 May 2013.

64. Lionte, C.; Sorodoc, V.; Jaba, E.; Botezat, A. Development and validation of a risk-prediction nomogram for in-hospital mortality in adults poisoned with drugs and nonpharmaceutical agents. An observational study. Medicine 2017, 96, e6404. [CrossRef]

65. Zhang, Z.; Kattan, M.W. Drawing Nomograms with R: Applications to categorical outcome and survival data. Ann. Transl. Med. 2017, 5, 211. [CrossRef]

66. Jaba, E.; Robu, I.B.; Anghel, I.; Roman, M.D. Development of a prognostic nomogram for bankruptcy risk estimation. In Proceedings of the 10th International Conference Globalization and Higher Education in Economics and Business Administration-GEBA 2017, Iasi, Romania, 19-22 October 2017; Faculty of Economics and Business Administration, Alexandru Ioan Cuza University of Iasi, UAIC University Press: Iasi, Romania, 2017. Available online: https://www.reserachgate.net/profile/Elisabeta_Jaba/publicaton/326266454_ Deleopment_of_a_prognostic_nomogram_for_bankruptcy_risk_estimation/ (accessed on 2 August 2019).

67. Wahba, H. Does the Market Value Corporate Environmental Responsibility? Corp. Soc. Responsib. Environ. Manag. 2008, 15, 89-99. [CrossRef]

68. Lewis, K.; Cassells, S. SMEs and Environmental Responsibility: Do Actions Reflect Attitudes? Corp. Soc. Responsib. Environ. Manag. 2011, 18, 186-199.

69. Baumann-Pauly, D.; Wickert, C.; Spence, L.J.; Scherer, A.G. Organizing corporate social responsibility in small and large firms: Size matters. J. Bus. Ethics 2013, 115, 693-705. [CrossRef]

70. Ferri, G.; Pini, M. Environmental vs. Social Responsibility in the Firm. Evidence from Italy. Sustainability 2019, 11, 4277. [CrossRef]

71. Badulescu, A.; Badulescu, D.; Saveanu, T.; Hatos, R. The Relationship between Firm Size and Age, and Its Social Responsibility Actions-Focus on a Developing Country (Romania). Sustainability 2018, 10, 805. [CrossRef]

72. Feltham, S.A. Snapshot of CSR in Central and Eastern Europe. 5 October 2016. Available online: www. triplepundit.com (accessed on 15 July 2019).

73. Horvath, P.; Putter, J.M.; Haldma, T.; Lääts, K.; Dimante, D.; Dagiliene, L.; Kochalski, C.; Ratajczak, P.; Wagner, J.; Petera, P.; et al. Sustainability Reporting in Central and Eastern European Companies: Results of an International and Empirical Study. In Book Sustainability Reporting in Central and Eastern European Companies International Empirical Insights; Horvath, P., Putter, J.M., Eds.; Springer International Publishing AG: Cham, Switzerland, 2017. [CrossRef]

74. Mihai, C.; Borza, M.; Talmaciu, M. Reaching the Objectives of Sustainable Development on the Basis of the Creative Industries-A South and Eastern European Analysis. Sci. Ann. Econ. Bus. 2016, 63, 117-124. [CrossRef]

(C) 2019 by the authors. Licensee MDPI, Basel, Switzerland. This article is an open access article distributed under the terms and conditions of the Creative Commons Attribution (CC BY) license (http://creativecommons.org/licenses/by/4.0/). 